\title{
Executives' Personal Tax Behavior and Corporate Tax Avoidance Consistency
}

\author{
Tomas HJELSTRÖM \\ Stockholm School of Economics \\ Juka-Pekka KALLUNKI \\ University of Oulu \\ Juha-Pekka.Kallunki@ oulu.fi \\ Henrik NILSSON \\ Stockholm School of Economics \\ Milda TYLAITE \\ Stockholm School of Economics
}

\begin{abstract}
We analyze executives' (CEOs, CFOs, and Board Chairpersons) personal tax returns to investigate whether and how their personal tax behavior is associated with the tax avoidance of their firms. We develop various measures of executives' personal tax behavior that are related to their personal risk propensity, ethics, financial incentives, and awareness of tax planning opportunities and risks. Our empirical results show that CEOs' and CFOs' personal tax behavior is related both to nonconforming and conforming corporate tax avoidance. We find no such results for Board Chairpersons.
\end{abstract}

JEL Classification: K3; L5; H2; H3

Keywords: taxation, tax avoidance, executive personal traits, behavioral consistency

Accepted by Martin Jacob.

Date of first submission: March 13, 2017

Date of final acceptance: May 16, 2019

Additional materials are available in an online Supplement at the journal's Taylor and Francis website.

\section{Funding}

This work was supported by the Handelsbanken Research Foundation under Grant P20130242:1

\section{Acknowledgements}

We thank Martin Jacob (editor), two anonymous referees, and participants at the 5th Annual Workshop on Current Research in Taxation, 39th EAA Annual Conference, and Second Annual Scandinavian Accounting Research Conference for many useful comments. 


\section{Introduction}

'In winter 2014, it was revealed that tax authorities in Luxembourg have helped hundreds of international companies with aggressive tax planning. With the direct help of the tax authorities, Swedish companies ... have managed for years to reduce their taxes substantially. Some companies have succeeded so well with this trickery that they have not paid any corporate tax at all.

In recent years, corporate tax avoidance has received increased public interest, and many political initiatives have been taken to restrict such behavior, including EU initiatives on tax information exchange and tax haven elimination. ${ }^{1}$ Moreover, a growing body of academic literature has explored the market-, firm-, and manager-specific determinants of corporate tax avoidance. For instance, many studies show associations between various firm-specific factors such as the size, profitability, financing choices, and organizational structure of the firm and the extent of corporate tax avoidance (Chen, Chen, Cheng, \& Shevlin, 2010; Chyz, 2013; Dyreng, Hanlon, \& Maydew, 2010; Gupta \& Newberry, 1997).

It has also been reported that executives' personal characteristics, such as their tendency for risk-taking behavior, integrity, or narcissism, are related to their firms' extent of tax avoidance. For instance, female CFOs tend to be less tax aggressive than male CFOs (Francis, Hasan, Wu, \& Yan, 2014), CEO integrity is negatively related to corporate tax avoidance (Law \& Mills, 2016), and CEO narcissism is positively related to the likelihood that a firm uses corporate tax shelters (Olsen \& Stekelberg, 2015). Others find that corporate tax avoidance is related to certain types of personal tax avoidance behavior by executives, such as stock option exercise backdating (Chyz, 2013) and recognizing capital gains before a tax rate increase (Cavazos \&

\footnotetext{
${ }^{1}$ In 2014, journalists revealed corporate tax avoidance schemes set up in Luxembourg for hundreds of European companies from 2002 to 2010, including 27 companies from Sweden. This led to the international scandal known as the Luxembourg Leaks. In 2015, a scandal known as the Swiss Leaks described thousands of individuals involved in a huge personal tax evasion scheme set up by one of the world's largest banks. In 2016, the so-called Panama papers revealed similar tax evasion schemes.
} 
Silva, 2017). However, the questions of what drives executives' personal tax behavior and what types of such behavior are associated with the tax avoidance of their firms are still largely unresolved.

In this paper, we investigate how the broad spectrum of personal tax behavior of the CEOs, CFOs, and Board Chairpersons of Swedish listed firms is associated with the tax avoidance behavior of their firms. We conduct our study using data from Sweden, because the unique personal tax returns data and criminal offense data available for all executives of Swedish listed firms enable us to develop direct and fine-grained measures of executives' personal tax behavior.

We expand previous studies on corporate tax avoidance by opening up the black box of executives' personal tax behavior and by linking it to corporate tax avoidance behavior. Specifically, we contribute to the literature in the following ways. First, we use various, finegrained measures of executives' personal tax behavior so as to capture a broad spectrum of such behavior, whereas previous research has used indirect proxies like stock option exercise backdating (e.g. Chyz, 2013) ${ }^{2}$. Second, we examine whether the measures of executives' personal tax behavior reflect their personal characteristics such as their personal risk propensity and ethics, financial incentives, and the awareness of tax planning opportunities and risks. Third, we investigate several alternative explanations of the association between personal tax behavior and corporate tax avoidance, our results showing that CEOs and, to some extent, CFOs have a discretionary impact on corporate tax avoidance that their superiors have not considered nor foreseen. Finally, we are the first to examine whether executives' personal tax behavior is consistently related to both non-conforming and conforming corporate tax avoidance strategies.

\footnotetext{
${ }^{2}$ While our measures pertain to the Swedish tax reporting rules to some extent, we believe that our results are applicable to other jurisdictions, because we focus on executives' personal tax behavior rather than on specific tax avoidance techniques, and because the level of corporate governance in Sweden is comparable to that of other developed countries. Specifically, Sweden's corporate governance rankings are similar to those of e.g. the United Kingdom, United States, Canada, Switzerland, or Germany (Schwab \& Porter, 2006).
} 
Our results of analyzing firms listed on the OMX Stockholm Stock Exchange in Sweden can be summarized as follows. First, we identify executives' personal tax behavior based on their matching of capital gains and losses, income reclassification, late or erroneous personal tax filings, and suspicions/convictions of tax crimes. We find that executives' personal tax behavior is driven by their personal ethics, risk propensity, the ability and awareness of tax-related opportunities and risks, and personal financial incentives, which previous literature has identified as drivers of personal tax planning or evasion (Alm \& Torgler, 2006; Alstadsæter \& Jacob, 2017; Bobek \& Hatfield, 2003; Collins, Milliron, \& Toy, 1992; Henderson \& Kaplan, 2005).

Second, we find that that the personal tax behavior of the CEOs and the CFOs is significantly related to both nonconforming and conforming tax avoidance behavior of their firms, and that this association is generally stronger for measures reflecting higher degrees of personal tax aggressiveness. We also investigate three potential sources of this association, i.e. executives choosing companies based on their tax behavior (firm-executive matching), executives being selected based on their personal tax style (selected style), and corporate tax avoidance behavior being adjusted to reflect executives' personal tax behavior (discretionary impact). We find no evidence that either CEOs or CFOs are matched with or selected to the firm based on their personal tax behavior. However, we find some evidence that the personal tax behavior of the CEOs and CFOs has a discretionary effect on corporate tax avoidance.

We organize the rest of the paper as follows. In the next section, we review the relevant literature and develop our hypotheses. In the third section, we describe the data sources, variable construction, and methodology. We then report the results of our empirical analyses and provide concluding remarks. 


\section{Hypothesis Development}

\section{Personal Tax Behavior}

Many studies show that most taxpayers are honest in their tax reporting, regardless of the availability of opportunities to engage in tax evasion (Alexander \& Feinstein, 1987; Sheffrin \& Triest, 1992). However, individuals who comply with tax reporting requirements may still engage in legal and socially acceptable tax minimization techniques, depending on their financial incentives, access to tax management strategies, and awareness of such strategies (Alstadsæter \& Jacob, 2017; Collins et al., 1992). Thus, Alstadsæter and Jacob (2017) report that individuals in the highest marginal income tax bracket have greater financial incentives to engage in legal income shifting by converting personal income to corporate income, which is taxed at a substantially lower marginal tax rate. They also find that individuals who can reclassify their earned income due to the nature of their employment have better access to tax management strategies, and that those who participate in networks through which information about tax management strategies is disseminated are more aware of these strategies and more likely to engage in income shifting.

Regarding the intentional misreporting of taxes, i.e. tax evasion, the traditional economic view suggests that decision to evade taxes depends on the benefits of tax evasion, i.e. tax savings, and the costs of such behavior, i.e. probability of being caught and the resulting punishment (Allingham \& Sandmo, 1972). Moreover, personal characteristics such as personal risk propensity and ethics have been shown to modify the perceived costs of such behavior. Personal risk propensity is related to decision to evade taxes because tax evasion is a risky activity having expected gains, but also having a downside risk should such behavior be uncovered by the tax authorities. Individuals with high personal risk propensity thus are more likely to engage in tax evasion because they perceive the risk of being caught as lower (Bosco \& Mittone, 1997; Ghosh \& Crain, 1996). Decision to evade taxes is also related to personal 
ethics, because the degree of personal ethics is related to the perceived guilt and shame, or the intrinsic cost, of such behavior (Alm \& Torgler, 2006; Hanno \& Violette, 1996; Kaplan, Newberry, \& Reckers, 1997). Relying on the literature discussed above, we hypothesize as follows:

Hypothesis 1: Executives' personal ethics, risk propensity, financial incentives, and awareness of tax strategies are reflected in their personal tax behavior.

An important notion in previous literature is that different types of personal tax behavior are driven by different personal characteristics (Alstadsæter \& Jacob, 2017; Collins et al., 1992). Less aggressive, typically legal behavior is mainly driven by financial considerations, availability, and awareness of tax planning opportunities. In contrast, more aggressive personal tax behavior such as tax non-compliance or tax evasion has been reported to be related to personal ethics and risk propensity (Alm \& Torgler, 2006; Bosco \& Mittone, 1997; Ghosh \& Crain, 1996; Hanno \& Violette, 1996; Kaplan, Newberry, \& Reckers, 1997). Following these insights, we expect that less and more aggressive personal tax behaviors are related to different sets of personal characteristics:

Hypothesis 1a: Executives' less aggressive personal tax behavior is related to their financial incentives and awareness of tax strategies.

Hypothesis 1b: Executives' more aggressive personal tax behavior is related to their personal ethics, risk propensity, financial incentives, and awareness of tax strategies. 


\section{Personal and Corporate Tax Behavior Consistency}

Hambrick and Mason's (1984) upper echelons theory suggests that top corporate executives have their individual and unique styles, and that their unique style affects various corporate outcomes either in direct decision making or because of the 'tone at the top'. This insight has been verified by many empirical studies (Bamber, Jiang, \& Isabel, 2010; Bertrand \& Schoar, 2003; Dejong \& Ling, 2013; Ge, Matsumoto, \& Zhang, 2011). Other researchers report that specific personal characteristics of executives are related to corporate outcomes (Davidson, Dey, \& Smith, 2015; Kaplan, Klebanov, \& Sorensen, 2012; Malmendier \& Tate, 2005; Malmendier \& Tate, 2008; Schrand \& Zechman, 2012). Furthermore, corporate tax outcomes are found to involve managerial fixed effects (Dyreng et al., 2010) and to be related to executives' personal characteristics such as overconfidence, narcissism, integrity, and risk taking (Cain \& McKeon, 2016; Chyz et al., 2018; Olsen \& Stekelberg, 2015).

Empirical research on the effect of managerial characteristics on corporate outcomes is clouded by challenges in variable measurement. Specifically, a solid theoretical basis for relating managerial and corporate behavior is often missing, or a given managerial behavior might be a manifestation of managers' other personal characteristics. The so-called consistencybased approach mitigates these problems by relying on the psychological proposition that individuals' behavior in one situation predicts their behavior in another comparable situation (Cronqvist, Makhija, \& Yonker, 2012; Funder \& Colvin, 1991; Mischel \& Shoda, 1995). In other words, managers make similar choices in matters related to both their personal life and their firms.

Supporting the consistency-based approach, Cronqvist et al. (2012) show that CEOs make similar choices in their personal and corporate leverage decisions, and Kallunki and Pyykkö (2013) report that CEOs' and directors' past payment defaults increase the likelihood that their firms would experience financial distress. Chyz (2013) finds that executive insiders who engage 
in stock option exercise backdating also tend to engage in corporate tax sheltering. Cavazos and Silva (2017) show that executives who strategically realized capital gains before the increase in taxes that accompanied implementation of the American Taxpayer Relief Act and Healthcare Act also accelerated dividend payments and reduced the long-term effective cash tax rates of their firms. The results of the above-mentioned studies suggest that executives' personal tax behavior is related to the tax avoidance behavior of their firms. In other words, while personal tax avoidance approaches may typically not be directly applicable in corporate tax strategies, the preferences of tax aggressive executives are likely to be reflected in the overall level of the tax avoidance of their firms.

Based on the upper echelons theory, we expect that this association is strongest for CEOs and CFOs who are directly responsible for corporate performance and reporting outcomes (Habib \& Hossain, 2013) and formulate our second hypothesize as follows:

Hypothesis 2: There is a positive association between executives', especially CEOs' and CFOs', personal tax behavior and corporate tax avoidance.

\section{Research Design}

\section{Data Sources}

Our sample covers firms listed on the OMX Stockholm Stock Exchange in Sweden; the data come from the years 1999 to 2007 . We obtain individual-level data on the CEOs, CFOs, and Board Chairpersons of these firms from various nationwide official databases maintained by the Swedish Tax Agency (Skatteverket), the Swedish National Council for Crime Prevention (Brå), the Swedish National Service Administration, the credit bureau UC, and Statistics 
Sweden. ${ }^{3}$ All these data are in electronic form, and we use executives' unique personal identity numbers (social security numbers) to match different databases.

The final sample contains 2,010 firm-year observations and 1,446 executives who served as CEOs, CFOs, or Board Chairpersons. Table 1 describes the sample construction in greater detail.

(Insert Table 1 here)

\section{Personal Tax Returns and Tax Crime Data}

We obtain data on executives' tax returns from the Swedish Tax Agency. ${ }^{4}$ The data cover all items in the tax returns, including the values of the estates owned, the type and amount of income, detailed information on dividend income, realized capital gains and losses, and the amounts of debt and other liabilities. The data also contain personal tax non-compliance records, including the administrative sanctions imposed by the Swedish Tax Agency if an executive failed to either supply the correct information on the tax returns or did not file on time.

Data on executives' criminal activity, including tax evasion, is obtained from the Swedish National Council for Crime Prevention. These data contain all court decisions on criminal convictions since 1974. Criminal convictions indicate clear criminal activity, but including only actual convictions in the analysis could lead to selection bias (Amir, Kallunki, \& Nilsson, 2014), because the burden of proof is heavier for more serious crimes, potentially causing these crimes to be underrepresented in the dataset of actual criminal convictions. We reduce this selection bias by including in our analyses those instances in which executives were suspected of serious

\footnotetext{
${ }^{3}$ Our sample period ends in 2007 because the Swedish Tax Agency has not collected data on taxpayers' personal wealth since 2007.

${ }^{4}$ The Swedish Tax Agency is equivalent to the Canadian Revenue Service or the Internal Revenue Service in the United States.
} 
tax as well as non-tax crimes since 1991. Suspicion of a crime means that a police investigation was launched, but that the prosecutor eventually decided not to pursue the case in court. We extract information about tax-related and non-tax cases from these datasets separately. Since suspicions and convictions of tax crime for these executives can be related to the tax evasion of their firms rather their personal behavior, we manually check each of these cases. If a given case is potentially related to the firm in which the executive serves during our sample period, we eliminate such executives and the firm-years of their service from the sample to limit endogeneity concerns ${ }^{5}$.

\section{Bankruptcy Involvements, Demographic Data, and Firm-Level Accounting Data}

Information on executives' involvements in bankruptcies is obtained from the Swedish credit bureau UC. These data identify executives who have served as CEOs or board members of private firms that have filed for bankruptcy. Data on executives' year of birth and education is obtained from Statistics Sweden. Finally, we retrieve the accounting data for our sample firms from the Compustat Global Vantage database. In the few cases of missing data in the database, we retrieve the missing data from Datastream and from the financial reports of the sample firms.

\footnotetext{
${ }^{5}$ The data obtained from the National Board of Crime Prevention does not disclose the specific reason for tax-related suspicions and convictions. However, we expect that executives suspected or convicted of tax crimes pertaining to their firms are likely to be dismissed following such events and are unlikely to be hired in other listed firms. In our sample, CEOs and Board Chairpersons typically remained in their positions around these decisions. On the other hand, all five instances when CFOs are suspected of tax crimes (there are no instances of $\mathrm{CFO}$ convictions in the sample) are related to $\mathrm{CFO}$ departures from the firm either shortly before or after the decision. These executives also have not been rehired in listed firms as CEOs, CFOs, or Board Chairpersons during our sample period. We thus conclude that all the cases of potential CFO tax evasion are likely related to their firms, and exclude from the sample the five CFOs, seven CEOs, and three Board Chairpersons who served together with these CFOs.
} 


\section{Variable Measurement}

\section{Measures of Executives' Personal Tax Behavior}

We construct five personal tax behavior measures and code each of them as equal to 1 if an executive has engaged in a given activity at least once during the study period and 0 otherwise. Specifically, we examine the following activities: (1) the matching of realized capital gains and losses, (2) dividend income from a closely held company, (3) late personal tax returns, (4) tax non-compliance (as indicated the imposition of administrative penalties by tax authorities for incorrectly filed tax returns), and (5) being suspected or convicted of tax crimes. These activities capture a broad spectrum of personal tax aggressiveness, because they reflect different levels of accessibility and legitimacy of tax behavior (see e.g. Alstadsæter \& Jacob, 2017; Cavazos \& Silva, 2017; Chyz, 2013).

Matching of capital gains and losses. Matching realized capital gains and losses is virtually risk-free and is among the most easily accessible tax avoidance strategies. In Sweden, realized capital gains are taxed at $30 \%$. However, realized capital gains up to 100,000 SEK per year can be fully matched against realized capital losses. Any losses exceeding the 100,000 SEK benchmark can be matched with realized gains using a $21 \%$ tax rate, which reduces the effectiveness of the matching to $70 \%$. We construct an indicator variable, $M A T C H_{i}$, that takes the value of 1 if an executive has matched realized capital gains and losses during at least $70 \%$ of the years for which personal tax filings by that executive are available. ${ }^{6}$ We use this indicator

\footnotetext{
${ }^{6}$ For example, if personal tax filings were available for the whole 1999-2007 period, we require realized capital gains and losses to have been matched during at least seven of those nine years to meet the $70 \%$ criteria. We do not use any matching ratios, because such measures would not fully capture tax avoidance behavior of executives with successful investment track record. In additional tests (not tabulated), we also perform our analyses with indicators based on alternative matching frequency requirements. Higher cutoff levels, such as $100 \%$, yield weaker results, likely because such requirement to a large extent captures unsuccessful investment behavior. The results are insignificant, if we require only one instance of a given tax avoidance behavior.
} 
as a proxy of least-aggressive personal tax behavior. Following Alstadsæter and Jacob (2017), we expect this behavior to be primarily driven by financial incentives.

Dividend income via a closely held company. Due to differences in salary and dividend income taxation in Sweden, income reclassification from salary to dividends can yield up to 17 $\%$ (until 2006; up to $27 \%$ after 2006) income tax rate difference. Such reclassification, however, requires owning a company in which income is reported and then paid out as dividends ${ }^{7}$. Thus, such personal tax planning strategy requires relatively more intentional effort and knowledge. It can also be seen as risky behavior should the Swedish Tax Agency see the revenue reported in such firm be seen as de facto external salary income.

We construct an indicator variable, RECLASS, that takes the value of 1 if an executive reports significant dividend income via a closely held company ${ }^{8}$ (i.e., annual dividend income exceeding 500,000 $\mathrm{SEK}^{9}$ ) at least once during the sample period. We choose a higher threshold for income shifting than the one used by Alstadsæter and Jacob (2017) so as to limit the risk of capturing ordinary dividend income instead of actively shifted income and to ensure that the potential tax gains achieved by the executive are sizable enough to create a motivation for such

\footnotetext{
${ }^{7}$ Alstadsæter and Jacob (2017) describe in detail the shifting of salary income to dividend income through closely held companies. In Sweden, salary income is subject to municipal tax, two levels of state tax, and social security tax. During our sample period, the maximum effective salary income tax rate varied between $66.4 \%$ and $67.2 \%$. Dividend income from closely held companies was subject to the corporate income tax of $28 \%$ and then a dividend income tax of $30 \%$ on the remaining amount, thus yielding an effective dividend income tax rate of $49.6 \%$. Moreover, the 2006 tax reform introduced a dividend allowance that was taxed at $20 \%$ within closely held companies, further decreasing the effective dividend tax rate to $42.4 \%$. Even before this reform, the highest-income individuals could have reduced their marginal tax rate by approximately $17 \%$ by shifting their salary income to dividend income. Although the executives of listed firms cannot shift their direct salary income, they can do so with income from various consulting, board, and other assignments.

${ }^{8}$ Swedish regulation defines a closely held company as a company controlled by four or fewer individual owners or groups of owners. Since we do not have ownership data for private firms, we define a closely held company as one that has paid dividends to three or fewer individuals listed as insiders in publicly listed companies.

${ }^{9}$ We repeat our analyses by using a threshold of 1,000,000 SEK, and the results are very similar. We also use alternative measure specification that requires multiple instances of suspected income reclassification, with similar results.
} 
income shifting. ${ }^{10}$ We use this indicator as a proxy for legal, but somewhat more aggressive personal tax behavior. Following Alstadsæter and Jacob (2017) and Collins et al. (1992), we expect this type of personal tax behavior to be primarily driven by personal risk propensity, financial incentives, and awareness of tax planning opportunities.

Late tax filings. Individual Swedish tax payers are required to file their tax returns until the $2^{\text {nd }}$ of May every year. The Swedish Tax Agency imposes late fees, typically 1,000 SEK (equal to about \$120 USD), when a taxpayer fails to file on time (The Swedish Tax Agency, 2011). This charge does not create any additional financial, legal, or financial risk to the taxpayer. However, such behavior may indicate loose ethical attitudes toward tax and reporting regulations (Reckers, Sanders, \& Roark, 1994). We construct an indicator variable, LATETAX, that takes the value of 1 if late fees are imposed on an executive at least once during the study period $^{11}$. We use this indicator as a proxy for somewhat aggressive personal tax behavior. Based on previous literature (Bosco \& Mittone, 1997; Collins et al., 1992; Ghosh \& Crain, 1996; Reckers et al., 1994), we expect it to be primarily driven by personal ethics and risk propensity.

Tax non-compliance. Personal tax filings may contain errors that yield tax surcharges, the amount of the surcharge typically being $20 \%$ to $40 \%$ of the unpaid tax (The Swedish Tax Agency, 2011). Like late fees, these surcharges are administrative sanctions that do not create a substantial financial or legal risk for the non-compliant taxpayer. However, such behavior may indicate the presence of underlying tax avoidance activities that might have been reported too aggressively ${ }^{12}$ ( Kaplan et al., 1997).

\footnotetext{
${ }^{10}$ We check whether CEO and CFO income reclassification behavior accessibility is limited only to those executives who receive income from their service at the board, as board members are able to reclassify their income from such engagements. We find no significant differences between the board memberships of the executives who report substantial dividend income and those who do not, suggesting that income reclassification behavior is not limited by accessibility in terms of board membership.

${ }^{11}$ In untabulated analysis, we modify the LATETAX $X_{i}$ measure such that it takes the value of 1 in the case of multiple instances of late tax filings, and obtain results that are similar to those reported in this paper. ${ }^{12}$ Anecdotal evidence suggests that surcharges are typically faced by individuals with complex income and compensation structures, e.g. top executives with external assignments and entrepreneurs, when certain types of income are not reported or misclassified.
} 
Accordingly, we construct an indicator variable, TAXERROR $R_{i}$, that takes the value of 1 if tax surcharges are imposed on an executive at least once during the study period. We only require one instance of tax surcharges because only two CEOs, two CFOs and three Board Chairpersons in the sample have filed incorrect tax returns on multiple occasions. This variable captures loose attitudes towards tax reporting and indicates inappropriate tax avoidance activity, although it does not meet the criteria of actual tax crime. We thus use this measure as a proxy for more aggressive personal tax behavior. Following the insights on tax avoidance and evasion in previous literature, we expect this type of behavior to be primarily driven by personal ethics, risk propensity, and financial incentives (Bosco \& Mittone, 1997; Collins et al., 1992; Ghosh \& Crain, 1996; Hanno \& Violette, 1996).

Extreme tax behavior. Finally, being suspected or convicted of tax crimes is an indicator of tax avoidance activities that cross (or have the potential to cross) legal boundaries. We construct an indicator variable, TAXEXTREME $E_{i}$, that takes the value of 1 if an executive has been suspected of criminal tax-related activity since 1991 or convicted of such activity since $1974 .{ }^{13}$ Because engaging in criminal tax avoidance is an indication of aggressive and intentional tax avoidance activity, we use this variable as an indicator of the most aggressive personal tax behavior. Drawing on previous literature on personal tax evasion, we expect it to be strongly driven by personal ethics (Alm \& Torgler, 2006; Hanno \& Violette, 1996; Kaplan, Newberry, \& Reckers, 1997).

We construct a composite variable to measure the spectrum of executives' personal tax behavior based on the indicator variables described above. The variable TAXTOTAL $L_{i}$ measures total personal tax behavior and is constructed as follows:

(1) TAXTOTAL $L_{i}=$ MATCH $_{i}+$ RECLASS $_{i}+$ LATETAX $_{i}+$ TAXERROR $_{i}+$ TAXEXTREME $_{i}$

\footnotetext{
${ }^{13}$ We use full sample periods available in the databases of tax-related suspicions and convictions.
} 
Table 2 reports the frequency distributions of each personal tax behavior measures and the composite variable TAXTOTAL $i$. The results reported in Panel A of Table 2 show that the most frequent personal tax avoidance strategy is the matching of realized capital gains and losses $\left(\mathrm{MATCH}_{i}\right) ; 13 \%$ of executives' were engaged in this activity. The results reported in Panel B of Table 2 show that $24.55 \%(75.45 \%)$ of the executives in our sample has (has not) engaged in at least one type of personal tax behavior.

(Insert Table 2 about here)

Our personal tax behavior measures have some obvious limitations. For instance, executives may also engage in other types of tax avoidance not covered by our measures. However, we mitigate this potential bias in our analyses by measuring a broad spectrum of executives' personal tax behavior. Another potential limitation is that certain behavior, when occurring only once during the sample period, may be accidental. On the other hand, requiring a given behavior to occur several times increases the risk that certain executives are misclassified as exhibiting no tax aggressive behavior. We address these concerns by conducting robustness checks and by using alternative specifications of executives' personal tax behavior measures. Finally, we weight the measures of executives personal tax behavior equally when calculating the composite measure TAXTOTAL $L_{i}$, although some other weighting might be more reliable. We address this concern by reporting our main results for each personal tax behavior measure individually.

\section{Determinants of Personal Tax Behavior}

Table 3 reports the descriptive statistics for the determinants of personal tax behavior. We measure executives' personal risk propensity by using two variables. First, we use an 
executive's age at the beginning of the sample period $\left(A G E_{i}\right)$, because Bertrand and Schoar (2003) report that older executives tend to be less risk tolerant than younger executives. The bankruptcy involvement track record, NBANKRUPTCY, measures the number of bankruptcies of listed or private companies in which an executive served either as a CEO or as a board member during the sample period. Previous studies show that risk-seeking persons are likely to self-select into firms that have a greater risk of bankruptcy (Malmendier, Tate, \& Yan, 2011; Platt \& Platt, 2012). Bankruptcy involvement track record therefore serves as a proxy for personal risk propensity. NBANKRUPTCY $Y_{f t}$ is winzorized at 99 percent, corresponding to 35 bankruptcies.

We measure an executive's personal ethics by the total number of instances in which the executive is suspected or convicted of non-tax crimes (TOTALCRIME $E_{i}$ ), because previous studies show that criminal behavior reflects a propensity to engage in unethical behavior (Tangney, Stuewig, \& Mashek, 2007).

Finally, we employ three proxies for an executive's awareness of and ability to implement tax planning strategies. Based on previous literature (e.g., Murray, 1998), we use an executive's average net wealth during his or her tenure $\left(W E A L T H_{i}\right.$, calculated as the natural log of average net wealth in SEK'000, winzorized at $1 \%$ and $99 \%$ ) as an indicator of the degree of financial incentive for personal tax avoidance, ${ }^{14}$ average annual salary during his or her tenure $\left(S A L A R Y_{i}\right.$, calculated as the natural log of average annual salary in SEK'000, winzorized at $1 \%$ and 99\%) as a proxy for general ability, and business education (SSEDEGREE $)_{i}$ to represent awareness

\footnotetext{
${ }^{14}$ High level of salary can create financial incentives for personal tax avoidance (Alstadsæter \& Jacob, 2017). However, because the top executives may not be able to divert their salary income, we expect to capture financial incentives more effectively by the level of their wealth.
} 
of tax avoidance opportunities. This last variable takes the value of 1 if the executive has a degree from the Stockholm School of Economics ${ }^{15}$ and 0 otherwise. ${ }^{16}$

(Insert Table 3 here)

\section{Measures of Corporate Tax Avoidance}

Measures based on book-tax differences. We calculate the book-tax difference $\left(B T D_{f t}\right)$, book-current tax difference $\left(C R T D_{f t}\right)$, and book-cash tax difference $\left(C T D_{f t}\right)$ to measure corporate tax avoidance as follows:

$$
\begin{aligned}
& B T D_{f t}=\left[\left(P I_{f t}+S P I_{f t}\right) \times 0.28-T X T_{f t}\right] / A T_{f t-1} \\
& C R T D_{f t}=\left[\left(P I_{f t}+S P I_{f t}\right) \times 0.28-T X C_{f t}\right] / A T_{f t-1} \\
& C T D_{f t}=\left[\left(P I_{f t}+S P I_{f t}\right) \times 0.28-T X P D_{f t}\right] / A T_{f t-1},
\end{aligned}
$$

where 0.28 is the corporate income tax rate in our sample period and $P I_{f t}, S P I_{f t}, T X T_{f t}, T X C_{f t}$, $T X P D_{f t}$, and $A T_{f t}$ are the Compustat Global abbreviations for pretax income, special items, total tax, taxes paid, current portion of total tax, and total assets, respectively. All the book-tax difference variables are winsorized at $1 \%$ and $99 \%$.

$B T D_{f t}, C T D_{f t}$, and $C R T D_{f t}$ capture different aspects of corporate tax avoidance. In particular, whereas $B T D_{f t}$ measures tax avoidance related only to permanent book-tax differences, $C T D_{f t}$ also includes temporary book-tax differences. $C T D_{f t}$, however, depends on the payment structures in the specific jurisdictions and might reflect delayed effects from the decisions made by tax authorities or by the firm in previous years. Finally, $C R T D_{f t}$, which is theoretically

\footnotetext{
${ }^{15}$ Although $45 \%$ of the executives in our sample have a degree in business or economics, those having a degree from the Stockholm School of Economics are more likely to be in a tight network in which information about specific opportunities, including tax avoidance possibilities, is spread (Brass, Butterfield, \& Skaggs, 1998).

${ }^{16}$ Detailed descriptive statistics by individual position are reported in Table A1 in the Online Appendix.
} 
appealing but rarely used in the literature (Donohoe \& Knechel, 2014), captures both the permanent and temporary book-tax differences and measures taxes to be paid for the income of the current year only. This measure can be distorted only when adjustments are made for the previous year's reported taxes and these adjustments are accounted for in the current year, therefore making it particularly suitable for the short-term tax behavior evaluation.

Effective tax rates. We also use the total $\left(G A A P E T R_{f t}\right)$, current $\left(C U R R E T R_{f t}\right)$, and cash $\left(\right.$ CASHETR $\left._{f t}\right)$ effective tax rates to measure corporate tax avoidance:

$$
\begin{aligned}
& \text { GAAPETR }_{f t}=T X T_{f t} /\left(P I_{f t}+S P I_{f t}\right) \\
& \text { CURRETR }_{f t}=T X C_{f t} /\left(P I_{f t}+S P I_{f t}\right) \\
& \text { CASHETR }_{f t}=T X P D_{f t} /\left(P I_{f t}+S P I_{f t}\right)
\end{aligned}
$$

We calculate effective tax rates for all firm-years with a positive pretax result, which comprise $69.8 \%$ of firm-year observations. All the effective tax rate variables are winsorized at 0 and 1 .

Conforming tax avoidance measure. The book-tax differences and effective tax rates discussed above measure nonconforming tax avoidance that arises from differences between tax filings and financial reports. To explore whether executives' personal and corporate tax behavior consistency holds in the conforming tax avoidance setting, i.e., when both taxable and reported income are suppressed for tax avoidance purposes, we also examine conforming corporate tax avoidance in our analyses. Previous literature suggests that firms with lower capital market pressures, lower information asymmetries, and upon regulatory or reporting changes, are likely to manage down their pre-tax profit to reduce their tax burden (Badertscher, Katz, Rego, \& Wilson, 2019; Guenther, 1994; Klassen, 1997; Penno \& Simon, 1986; Sundvik, 2017). Such tax planning strategy is thus not reflected in typical corporate tax avoidance 
measures, such as book-tax differences and effective tax rates, even though it may represent an important tax-driven reporting outcome ${ }^{17}$.

We measure conforming tax avoidance by using the variable CONFTAX $X_{f t}$, which is a residual from the following model suggested by Badertscher et al. (2019):

$$
\begin{aligned}
\frac{T X P D}{\operatorname{lag}(A T)_{f t}}= & \beta_{0}+\beta_{1} B T D_{f t}+\beta_{2} L_{O S S_{f t}}+\beta_{3} B T D_{f t} \times L_{O S S_{f t}}+\beta_{4} \frac{S A L E S}{N O A} f t \\
& +\beta_{5} N O L_{f t}+\varepsilon_{f t}
\end{aligned}
$$

We estimate equation (8) separately for each industry (based on Fama-French 12-industry classification) and year combination with at least six industry-year observations. CONFTAX $X_{f t}$ is winzorized at $1 \%$ and $99 \%$. Lower values of CONFTAX $X_{f t}$ indicate higher conforming tax avoidance.

Pros and cons of different corporate tax avoidance measures. We treat book-tax differences as our main measure of corporate tax avoidance, for several reasons. First, book-tax differences capture the whole continuum of corporate tax behavior. ${ }^{18}$ This is particularly important for our study, because we investigate the whole spectrum of personal tax behavior rather than only the extremes. Consequently, corporate tax avoidance measures should also reflect the full spectrum of corporate tax avoidance.

Second, in comparison to measures based on book-tax differences, effective tax rates are biased, because they are not meaningful for negative pretax income (Henry \& Sansing, 2018).

\footnotetext{
${ }^{17}$ Chen et al. (2010) show that family firms engage in less non-conforming tax avoidance than nonfamily firms. On the other hand, Badertscher et al. (2019), using the same sample, demonstrate that family firms engage in more conforming tax avoidance than non-family firms.

${ }^{18}$ This contrasts with Chyz (2013), who uses the TS-Score as a proxy of corporate tax avoidance. By design, the TS-Score captures only the probability of tax sheltering activities in the firm, but not other types of corporate tax avoidance. The firms in our subsample are likely to have governance practices that at least to some extent prevent extreme tax avoidance, such as tax sheltering. On the other hand, larger public firms due to their business complexity and ability to obtain external advisory services, may have more opportunities to engage in legal tax avoidance techniques. Book-tax differences are therefore more suitable in a setting where the aim is to capture broad tax behavior outcomes arising from a variety of strategies.
} 
Moreover, the cash-based effective tax rate overstates the firm's general tax avoidance level when the years of negative pretax income are deleted from the sample. In our sample, we lose about $30 \%$ of observations due to negative pretax income. Although this problem of overstating the level of tax avoidance can be mitigated by using a long-term cash-based effective tax rate (Dyreng, Hanlon, \& Maydew, 2008), it cannot be avoided when exploring short-term corporate tax avoidance behavior.

Third, effective tax rates can be substantially biased due to variation in pretax income, which is the denominator in the effective tax rate. More stable denominators like total assets reduce this bias and allow for a more consistent comparison between small and large firms, as well as a better evaluation of the economic relevance of corporate tax strategies (Henry \& Sansing, 2018).

The conforming tax avoidance measure captures still another dimension of corporate tax avoidance behavior, because it identifies firms that suppress their reported pretax and taxable income for tax minimization purposes. Such strategy, however, comes at a cost of potentially negative external shareholder reaction, and consequently is more likely to occur in privately held and closely controlled firms that are subject to little or no external shareholder pressure (Badertscher et al., 2019). However, it could be argued that consistency between CEOs' personal and corporate tax behavior should not be dependent on a specific (i.e., nonconforming or conforming) corporate tax behavior strategy. Using the conforming tax avoidance measure allows us to test whether that is indeed the case.

\section{Control Variables}

Previous studies show that corporate tax avoidance is associated with many firm-specific characteristics, such as business complexity and structure, profitability, asset mix, levels of expenses subject to tax deductions or credits, financial leverage, and liquidity (Chyz, 2013; Dyreng et al., 2010; Gupta \& Newberry, 1997). We therefore use various firm-specific variables 
in our multivariate analysis to control for the likely firm-specific determinants of corporate tax avoidance. Specifically, $S I Z E_{f t}$ is the natural logarithm of a firm's total assets in thousands of SEK; $E B I T D A_{f t}$ is the operating profit before depreciation divided by lagged assets; $R D_{f t}$ represents the research and development $(\mathrm{R} \& \mathrm{D})$ expenses divided by total sales; $S G A_{f t}$ is the sales, general, and administration (SG\&A) expenses divided by total sales; $C A P E X_{f t}$ signifies the capital expenditure divided by gross property, plant, and equipment (PP\&E);ChSALE $E_{f t}$ is the yearly percentage change in sales; $L E V E R A G E_{f t}$ is the total debt divided by total assets; $\mathrm{CASH}_{f t}$ stands for the cash and cash equivalents divided by total assets; INTANGRATIO $f$ is the amount of intangible assets divided by total assets; $P P E R A T I O_{f t}$ is the gross PP\&E divided by total assets; $P T \_R O A_{f t}$ is the pretax income divided by lagged total assets; $N O L_{f t}$ is an indicator variable taking the value of 1 if a company has experienced loss over the last three years; and $F S_{f t}$ is an indicator variable that takes the value of 1 if a company has reported positive foreign sales in a given year. All continuous firm-level control variables are winzorized at $1 \%$ and $99 \%$.

Since the quality of the firm's corporate governance may also affect corporate outcomes such as tax avoidance (Bear, Rahman, \& Post, 2010; Fich \& Shivdasani, 2006; Hermalin \& Weisbach, 2003; Jensen, 1993; Uzun, Szewczyk, \& Varma, 2004), we use the variables $B O A R D S I Z E_{f t}$ (number of board members), PROF_BOARD $D_{f t}$ (proportion of professional board members on the board), and FEMALE_BOARD $D_{f t}$ (proportion of female board members on the board) to control for corporate governance quality in our multivariate analysis.

Finally, to control for the effect of ownership and corporate incentives on corporate tax avoidance, we include the following controls: $O P T_{-} I N C_{f t}$ is an indicator variable set to 1 if the firm reports using option compensation; CEO_INS $S_{f t}\left(C F O \_I N S_{f t} ; C H A I R \_I N S_{f t}\right)$ is a percentage of CEO's (CFO's; Board Chairperson's) insider holdings in her total wealth; INST_BLOCK $f$ is a number of institutional blockholders, i.e. institutional investors that own more than $5 \%$ of the 
shares; and CEO_OWNERSHIP ft $_{\text {it }}$ the proportion of shares owned by the CEO and her family members.

\section{Descriptive Statistics}

Table 4 reports descriptive statistics for the variables used in our analysis and the results of testing whether the means and medians of the variables are different between firm-years with and without CEOs, CFOs, and Board Chairpersons exhibiting personally aggressive tax behavior which we capture using TAXTOTAL . The results reported in Panel A of Table 4 show that the level of corporate tax avoidance for firms with CEOs who exhibit aggressive personal tax behavior is significantly higher than that for those firms without such CEOs. The results displayed in Panel B of Table 4 show that book-tax differences are higher (but effective tax rates are not lower) in firms where the CFO exhibits aggressive personal tax behavior. Finally, Panel $\mathrm{C}$ of Table 4 shows that the levels of corporate tax avoidance are not related to the personal tax behavior of the Board Chairperson ${ }^{19}$.

(Insert Table 4 here)

\section{Models}

Determinants of Executives' Personal Tax Behavior

We test Hypothesis 1 on the drivers of personal tax behavior by estimating the following ordered logistic regression model for the 1,391 executives (of whom 621 served as CEOs, 469 as CFOs, and 436 as Board Chairpersons during our sample period):

\footnotetext{
${ }^{19}$ Descriptive statistics for all variables used in empirical investigations are reported in Table A2 in the Online Appendix. Table A3 in the Online Appendix reports Pearson correlation coefficients between the variables used in our analyses.
} 


$$
\operatorname{Prob}\left(T A X B E H_{i}\right)=\frac{1}{1+e^{-Z}}
$$

where

$$
\begin{aligned}
& Z= \beta_{0}+\beta_{1} \text { AGE }_{i}+\beta_{2} \text { TOTALCRIME }_{i}+\beta_{3} \text { NBANKRUPTCY }_{i}+ \\
& \beta_{4} \text { WEALTH }_{i}+\beta_{5} \text { SALARY }_{i}+\beta_{6} \text { SSE DEGREE } \\
&+\varepsilon .
\end{aligned}
$$

The dependent variable $T A X B E H_{\mathrm{i}}$ is either $\mathrm{MATCH}_{i}$, RECLASS $_{i}$, LATETAX $_{i}$, TAXERROR $_{i}$, TAXEXTREME , or TAXTOTAL $_{i}$. Subscript $i$ refers to unique executives in our sample. All variables are as described above and in the Appendix. We expect an executive's age $\left(A G E_{i}\right)$ to be negatively related to the likelihood of aggressive tax behavior, because older executives are found to be less risk tolerant (Bertrand \& Schoar, 2003). We also expect bankruptcy involvements $\left(N B A N K R U P T C Y_{i}\right)$ and criminal suspicions or convictions of non-tax related crimes (TOTALCRIME $E_{i}$ ) to be positively related to the likelihood of tax aggressive behavior, because these variables measure one's propensity for personal risk and unethical behavior (Tangney et al., 2007). Following Hypotheses 1a and 1b, we expect personal ethics to be related to more aggressive tax behavior, and not be related to less aggressive tax behavior.

Furthermore, we expect the level of an executive's net wealth $\left(W E A L T H_{i}\right)$ to be positively related to the likelihood of engagement in personally aggressive tax behavior, because a high level of wealth creates greater opportunities and needs for effective tax management. We also expect an executive's salary $\left(S A L A R Y_{i}\right)$ to serve as a measure of that executive's general ability (e.g. Murray, 1998), and thus to be positively related to less aggressive tax behavior because more able executives are likely to be more able to identify tax saving opportunities. We do not expect to observe the same association for more aggressive tax behavior because more able executives may be more likely to recognize risks related to such behavior. Finally, we expect education $\left(S S E D E G R E E_{i}\right)$ to be positively related to an executive's less aggressive tax behavior, because higher education generally leads to greater awareness of tax planning opportunities (Alstadsæter \& Jacob, 2017), and negatively related to extreme personal tax 
behavior, because this higher education also creates better understanding of the risks associated with such behavior.

\section{Executives' Personal and Corporate Tax Behavior Consistency}

We test Hypothesis 2 on the relationship between executives' personal tax behavior and corporate tax avoidance by estimating the following ordinary least squares (OLS) regression from our sample:

$$
\begin{aligned}
& \text { CORPTAX }_{f t}=\beta_{0}+\beta_{1 a} \text { TAXBEH_CEO } f t+\beta_{1 b} \text { TAXBEH_CFO } f t+ \\
& \beta_{1 c} T A X B E H_{-} C H A I R_{f t}+\beta_{1 d} L O S S_{f t}+\beta_{1 e} T A X B E H_{-} C E O_{f t} \times
\end{aligned}
$$

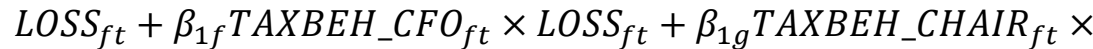

$$
\begin{aligned}
& L_{O S S}+\sum \text { CONTROLS }+\sum \text { Industry FE }+\sum \text { Year FE }+\varepsilon \text {, }
\end{aligned}
$$

where the dependent variable CORPTAX $X_{f t}$ is either the book-tax difference $\left(B T D_{f t}, C R T D_{f t}\right.$, or $\left.C T D_{f t}\right)$ or the effective tax rate $\left(\right.$ GAAPETR $_{f t}, C_{\text {CURETR }}$, CASHETR $\left._{f t}\right)$. The independent variables TAXBEH_CEOft, TAXBEH_CHAIRft, and TAXBEH_CFO $O_{f t}$ are the measures of personal tax behavior, i.e., either TAXTOTAL $L_{f t}$, or MATCHft, RECLASS $S_{f t}, L_{A T E T A X}$, TAXERROR $_{f t}$ and TAXEXTREME $E_{f t}$ for the CEO, CFO, and Board Chairperson of the firm, respectively. We use a number of firm-level control variables to ensure the robustness of the results regarding the association between executives' personal and corporate tax behavior (Dyreng et al., 2010). ${ }^{20}$ This vector of control variables includes incentive, governance, and firm level factors that may explain corporate tax avoidance levels. These variables are as defined in Section 'Variable Measurement' and in the Appendix. Subscripts $f t$ refer to specific firm-year observations. Finally, we use robust standard errors clustered by firm.

\footnotetext{
${ }^{20}$ In additional analysis, we also control for personal characteristics related to the personal tax behavior to mitigate potential omitted correlated variable bias. The associations remain significant after including these additional controls. See Table A5 in the Online Appendix for estimation results.
} 


\section{Empirical Results}

\section{Determinants of Executives' Personal Tax Behavior}

Table 5 reports the results of testing Hypotheses 1, 1a, and $1 \mathrm{~b}$ on the determinants of executives' personal tax behavior. These results show that an executive's personal ethics $\left(T_{O T A L C R I M E}\right)$, is significantly positively related to more aggressive personal tax behavior measured by late or wrong tax filling and by being suspected/convicted of tax crimes, but not to less aggressive personal tax behavior. An executive's personal risk propensity $\left(N B A N K R U P T C Y_{i}\right)$ is significantly positively related to income reclassification and late tax filings. An executive's personal financial incentives, measured as the extent of wealth $\left(W E A L T H_{i}\right)$ are significantly positively related to most of the personal tax behavior measures. Executives' ability, measured as total salary $\left(S A L A R Y_{i}\right)$, is positively related to matching of capital gains and losses, and negatively related to late tax filings. An academic degree from the Stockholm School of Economics $\left(S S E D E G R E E_{i}\right)$ is significantly negatively related to $T A X E X T R E M E_{i}$. Finally, an executive's age $\left(A G E_{i}\right)$ is generally not significantly related to personal tax behavior.

Overall, these results show that an executive's less aggressive tax behavior is primarily driven by her financial incentives, that an executive's ability and awareness of tax avoidance techniques are positively (negatively) related to her less (more) aggressive tax behavior, and that an executive's personal ethics is related to her more aggressive personal tax behavior. Taken together, these results support Hypothesis 1. These results also show that the level of the aggressiveness of an executive's personal tax behavior is driven by different types of her personal characteristics, thereby supporting Sub-hypotheses 1a and 1b.

(Insert Table 5 here) 


\section{Results from Personal and Corporate Tax Behavior Consistency Investigations}

Table 6 reports the results of estimating equation (10) to test Hypothesis 2 on the consistency between executives' personal tax behavior and corporate tax avoidance. Panel A of Table 6 reports the results using the book-tax differences as the dependent variables, whereas Panel B of Table 6 shows the results for the effective tax rates. For each dependent variable, we report two alternative model specifications using either the composite measure of executives' personal tax behavior $\left(T A X T O T A L_{f t}\right)$ or the individual measures comprising the composite measure.

The results reported in Table 6 support Hypothesis 2. Specifically, the results show that CEO_TAXTOTAL $L_{f t}$ is significantly associated with corporate tax avoidance in all six model specifications and that $C F O \_T A X T O T A L_{f t}$ is significantly related to corporate tax avoidance measured by book-tax differences ${ }^{21}$. A Board Chairperson's personal tax behavior $\left(\right.$ CHAIR_TAXTOTAL $\left.L_{f t}\right)$ is not significantly related to corporate tax avoidance ${ }^{22}$.

The results reported in Table 6 also show that the components of CEO and CFO personal tax behavior mostly have the predicted signs, and more aggressive personal tax behavior LATETAX $_{f t}$ and TAXERROR $f t$ is most often significantly related to corporate tax avoidance. However, no single component is consistently related to corporate tax avoidance. This result supports the notion that personal tax behavior is multidimensional and that no single measure

\footnotetext{
${ }^{21}$ Regarding our LuxLeaks quote in Introductory Section, we have examined whether there are firms in our sample that were also involved in Luxleaks. We find that three firms in our sample were involved in LuxLeaks and that all these firms had either CEO or CFO engaged in personally tax aggressive behavior according to our measures.

${ }^{22}$ The economic significance of these associations is as follows. One standard deviation increase in CEO_TAXTOTAL $L_{f t}$ yields a 0.03 standard deviation increase in $B T D_{f t}, C R T D_{f t}$, and $C T D_{f t}$ measures; this effect is about $14 \%$ of $E B I T D A_{f t}$ effect, $66 \%$ of $C h S A L E_{f t}$ effect, and $6 \%$ of PT_ROA $A_{f t}$ effect. In effective tax rate specifications, one-standard-deviation increase in $C E O_{-} T A X T O T A L_{f t}$ yields a 0.10 standard deviation decrease in dependent variables, corresponding to about $22 \%$ of $E B I T D A_{f t}$ effect, 40 $\%$ of PT_ROA ft effect, and $136 \%$ of $L E V E R A G E_{f t}$ effect.
} 
fully captures the whole spectrum of such behavior. The components of the Board Chairperson's personal tax behavior are not consistently related to corporate tax behavior ${ }^{23}$.

The results for the control variables included in these model specifications are generally in line with those reported in previous literature ${ }^{24}$. Most notably, firm size and profitability are positively, whereas liquidity, SG\&A expenses are negatively related to corporate tax avoidance levels. We do not find any significant relationship between the firm's intensity of R\&D and corporate tax avoidance. Finally, foreign sales are not significantly related to corporate tax avoidance.

(Insert Table 6 here)

\section{Additional Analyses}

The results in previous section show that personal tax behavior of the CEOs and the CFOs, but not that of Board Chairpersons, is significantly related to corporate tax avoidance. These results may arise through a number of mechanisms (Cronqvist et al., 2012; Fee, Hadlock, \& Pierce, 2013). For instance, executives with certain characteristics may be consistently matched with firms with certain types of behavior (the matching proposition), executives may be appointed because of their specific managerial styles that the firm aims to adopt (the selected style proposition), or executives may have idiosyncratic effects on corporate outcomes that were not foreseen when the hiring decision was made (the idiosyncratic effect proposition). In this section, we explore which of these factors could be a driving force behind the findings reported above.

\footnotetext{
${ }^{23}$ In additional analyses, we investigate the association between corporate tax avoidance and personal tax behavior by only using the cases of tax-related suspicions, and obtain similar results. See Table A6 in the Online Appendix for the estimation results.

${ }^{24}$ The detailed estimation results are reported in Table A4 in the Online Appendix.
} 
Analysis of the matching proposition. We first explore executives' personal and corporate tax behavior consistency in a turnover setting. Following Cronqvist et al. (2012), we investigate whether changes in executives' personal tax behavior are related to changes in corporate tax avoidance. The matching proposition is rejected, if the change in corporate tax avoidance is associated with the change in an executive's personal tax behavior, i.e. if corporate tax avoidance levels change in accordance with executives' preferences.

In our sample, there are 522 cases of executive (CEO and/or CFO) turnovers where personal tax behavior data are available on both the former and the new executives of the firm. We calculate changes in the corporate tax avoidance between the first year of the new executive team's tenure and the last year of the former team's tenure to investigate the immediate effects of executive turnover on corporate tax avoidance. We also calculate the changes in the average corporate tax avoidance by using the full tenure of both executive pairs, regardless of their duration to investigate the long-term effects of the executive turnover on corporate tax avoidance.

The results reported in Table 7 show that the changes in the executives' personal tax behavior due to a CEO and/or CFO turnover are significantly positively correlated with both immediate and longer-term changes in corporate tax avoidance in a univariate setting (Panel $\mathrm{C}$ of Table 7). ${ }^{25}$ To ensure that these associations are not driven by other firm-level factors, we also investigate this relationship in a multivariate setting, the results of which being reported in Panel D of Table 7. These results show a statistically significant association between executive personal tax behavior changes, arising due to executive turnover, and longer-term corporate tax avoidance even after controlling for the likely firm-level determinants of the changes in corporate tax avoidance. We also find some, though weaker, association between personal and

\footnotetext{
${ }^{25}$ However executive turnover itself is not significantly related to changes in corporate tax avoidance (means and medians of changes are not statistically different from zero), see Panel A of Table 7.
} 
corporate tax behavior change when we use one-year measures of corporate tax avoidance, a result consistent with the notion that it takes more than one year for a new executive to imprint personal preferences on corporate outcomes (Bertrand \& Schoar, 2003; Dyreng et al., 2010) ${ }^{26}$.

In sum, the results of analyzing executive turnovers suggest that change in the personal tax behavior of the CEO and CFO team is associated with corporate tax behavior change, which is against the matching proposition.

(Insert Table 7 here)

Analysis of the selected style proposition. We next investigate the nature of the causality between executives' personal tax behavior and corporate tax avoidance. Fee et al. (2013) argue that the corporate boards, in their selection of a new CEO, actively anticipate how the appointed CEO's arrival will affect major corporate policies. We therefore explore whether the causal effect of the executives on corporate tax avoidance can be explained by selection of the new executive based on her personal tax behavior.

In these analyses, we rely on the insights that Board Chairpersons play a key role in appointing the new CEO (Coles \& Hesterly, 2000; Schooley, Renner, \& Allen, 2010), that new CFO appointment decision can also be driven by the CEO, and that top executives and boards prefer to choose executives that are demographically similar to them (Zajac \& Westphal, 1996). Thus, we first investigate whether the Board Chairperson's personal characteristics predict those of the newly appointed CEO and CFO, and whether the personal characteristics of the CEO predict those of the new CFO.

\footnotetext{
${ }^{26} \mathrm{We}$ also perform these tests individually for CEO and CFO turnover. The results are consistent with the reported findings, showing that both CEO and CFO turnover are associated with corporate tax avoidance changes. We also investigate Board Chairpersons' turnovers but find no evidence of corporate tax avoidance changes associated with the change in Board Chairperson and her personal tax behavior.
} 
Although we address this selection concern by including CEOs', CFOs', and Board Chairpersons' personal tax behavior measures simultaneously in our main regressions, we also examine whether there is a match between the incoming CEO or CFO and incumbent Board Chairperson in terms of their personal tax behavior, age, education, bankruptcy involvements, criminal behavior, and wealth.

The results reported in Panel A of Table 8 show that there is a significantly positive correlation between the Board Chairperson and the new CEO for age and personal risk propensity (as measured by bankruptcy involvements), but not for other personal characteristics, including personal tax behavior. The results reported in Panels B and C of Table 8 show significant positive correlations between the new $\mathrm{CFO}$, the $\mathrm{CEO}$, and the Board Chairperson in terms of age, personal risk propensity, and wealth, but not personal tax behavior. Hence, we conclude that although executives are matched based on their age, general risk preferences, and wealth, there is no evidence that executive selection is based on personal tax behavior.

We then explore whether the former executives' characteristics predict those of the newly appointed executives. ${ }^{27}$ This analysis is motivated by Zajac and Westphal (1996), who find that similar characteristics of CEOs indicate similar behavioral tendencies. Hence, firms might repeatedly select similar executives that match their preferences best (Cronqvist et al., 2012). Should executives be repeatedly selected based on their personal tax preferences, one could presume that a deviation from such a match would likely reflect an intentional decision by the board.

\footnotetext{
${ }^{27}$ The number of CEO and CFO turnovers used in this analysis is different from the number of turnovers analyzed in the previous section due to different data requirements. In the analysis of predictability of the new executives' characteristics, we require age, education, bankruptcy involvement, crime, and tax returns for all executives. When analyzing the effects of executive turnover on corporate outcomes, we require only the data needed to calculate the variable TAXTOTAL $L_{i}$.
} 
The results reported in Panel D of Table 8 show a significantly positive relationship between the former and new CEO with regard to age, type of education, bankruptcy involvements, and level of wealth. The results for CFOs (Panel E of Table 8) show a significant positive association between the former and new $\mathrm{CFO}$ with regard to age and risk propensity. However, we do not find any significant relationship concerning personal tax behavior. These results suggest that firms tend to choose executives who are similar to their predecessors in their other personal characteristics, but not in their personal tax behavior.

Taken together, these results suggest that that corporate tax avoidance changes arise from idiosyncratic executive effects rather from any intentional attempt to choose executives who match board or CEO preferences in this regard.

(Insert Table 8 here)

\section{CEOs' Personal Tax Behavior and Conforming Corporate Tax Avoidance}

Corporate tax avoidance studies typically focus on nonconforming tax avoidance, i.e., booktax discrepancies arising from differences between financial statements and corporate tax filings. However, firms may also use conforming tax avoidance strategies that reduce both financial and taxable income and that are not captured by conventional tax avoidance measures. Since tax conscious executives may also rely on other but nonconforming tax avoidance strategies, we examine whether executives' personal tax behavior is related to conforming corporate tax avoidance behavior. We identify conforming corporate tax avoidance behavior by using the approach of Badertscher et al. (2019).

The results of these analyses are reported in Table 9. Panel A of Table 9 reports the descriptive statistics for the conforming corporate tax avoidance measure $\left(C O N F T A X_{f t}\right)$. In Panel B of Table 9, we report the results from the multivariate analysis of these associations. 
To ensure that our results are not driven by other factors that may affect corporate reporting choices, we control for firm size, use of option compensation, proportion of insider holding in total CEO, CFO, and Board Chairperson wealth, number of institutional blockholders, and the proportion of shares held by the CEO and her family. The results of this analysis show that CEO and CFO personal tax behavior are independently positively related to the levels of conforming tax avoidance (negative coefficients for CEO_TAXTOTAL $f t$ and CFO_TAXTOTALft . We also observe negative association between Board Chairperson's personal tax behavior and conforming tax avoidance (positive coefficient for CHAIR_TAXTOTAL $L_{f t}$ ). Such finding suggests that Board Chairperson's role in corporate reporting choices is driven by other factors than personal tax preferences, which is consistent with the proposition that Board Chairpersons are unlikely to be concentrating on corporate tax strategies. Larger firms and firms with CFOs with larger proportions of insider holdings in their total wealth are also significantly less likely to engage in conforming tax avoidance.

In Panel $\mathrm{C}$ of Table 9, we report the results of the executive change on conforming tax avoidance. We find a significant negative association between $C E O \_T A X T O T A L_{f t}$ change and CONFTAX $_{f t}$ change, indicating that changes in CEOs' personal tax behavior are positively related to changes in corporate conforming tax avoidance behavior. However, we do not find such associations for the CFOs. Overall, these findings on the conforming tax avoidance analysis support our expectation that executives' consistency in their personal and corporate tax behavior extends beyond nonconforming corporate tax avoidance measures.

(Insert Table 9 here) 


\section{Conclusions}

In this study, we use unique Swedish personal tax return data to explore the extent of consistency between top corporate decision makers' personal tax behavior and corporate tax avoidance. Using information from personal tax returns, we develop personal tax behavior measures that cover a broad spectrum of tax aggressiveness. We first show that executives' personal tax behavior is strongly related to their personal risk preferences, personal ethics, and financial incentives, and that different degrees of personal tax aggressiveness are driven by different sets of characteristics. Next, we find that CEOs' and CFOs' personal tax behavior is significantly related to the tax avoidance of their firms.

We conduct several additional analyses, which show that the observed positive association between executives' personal tax behavior and corporate tax avoidance appears to be driven by idiosyncratic executive effects rather than by any effort at executive-firm matching in this regard. Finally, we demonstrate that the consistency between executives' personal and corporate tax behavior also extends to conforming corporate tax avoidance strategies. 


\section{References}

Alexander, C., \& Feinstein, J. S. (1987). A microeconomic analysis of income tax evasion. Unpublished paper, Massachusetts Institute of Technology.

Allingham, M. G., \& Sandmo, A. (1972). Income tax evasion: a theoretical analysis. Journal of Public Economics, 1(3-4), 323-338. doi:http://dx.doi.org/10.1016/0047$\underline{\text { 2727(72)90010-2 }}$

Alm, J., \& Torgler, B. (2006). Culture differences and tax morale in the United States and in Europe. Journal of Economic Psychology, 27(2), 224-246. doi:http://dx.doi.org/10.1016/j.joep.2005.09.002

Alstadsæter, A., \& Jacob, M. (2017). Who participates in tax avoidance? Evidence from Swedish microdata. Applied Economics, 49(28), 2779-2796. doi:10.1080/00036846.2016.1248285

Amir, E., Kallunki, J., \& Nilsson, H. (2014). Criminal convictions and risk taking. Australian Journal of Management, 39(4), 497-523.

Badertscher, B. A., Katz, S. P., Rego, S. O., \& Wilson, R. J. (2019). Conforming tax avoidance and capital market pressure Accounting Review, In-Press.

Bamber, L. S., Jiang, J., \& Isabel, Y. W. (2010). What's My Style? The Influence of Top Managers on Voluntary Corporate Financial Disclosure. Accounting Review, 85(4), 1131-1162. doi:10.2308/accr.2010.85.4.1131

Bear, S., Rahman, N., \& Post, C. (2010). The Impact of Board Diversity and Gender Composition on Corporate Social Responsibility and Firm Reputation. Journal of Business Ethics, 97(2), 207-221. Retrieved from http://www.jstor.org/stable/40929405

Bertrand, M., \& Schoar, A. (2003). Managing with Style: the Effect of Managers on Firm Policies. Quarterly Journal of Economics, 118(4), 1169-1208. doi:10.1162/003355303322552775

Bobek, D. D., \& Hatfield, R. C. (2003). An investigation of the theory of planned behavior and the role of moral obligation in tax compliance. Behavioral Research in Accounting, 15, 13-38. Retrieved from http://search.proquest.com/docview/203293864?accountid=39039

Bosco, L., \& Mittone, L. (1997). Tax evasion and moral constraints: some experimental evidence. Kyklos, 50(3), 297-324.

Brass, D. J., Butterfield, K. D., \& Skaggs, B. C. (1998). Relationships and unethical behavior: A social network perspective. Academy of Management Review, 23(1), 14-31.

Cain, M. D., \& McKeon, S. B. (2016). CEO personal risk-taking and corporate policies. Journal of Financial and Quantitative Analysis, 51(1), 139-164. 
Cavazos, G. P., \& Silva, A. M. (2017). Tax-minded executives and corporate tax strategies: Evidence from the 2013 tax hikes. Available at SSRN 2529509.

Chen, S., Chen, X., Cheng, Q., \& Shevlin, T. (2010). Are family firms more tax aggressive than non-family firms? Journal of Financial Economics, 95(1), 41-61.

Chyz, J. A., Gaertner, F. B., Kausar, A., \& Watson, L. (2018). Overconfidence and Corporate Tax Policy. Available at SSRN 2408236.

Chyz, J. A. (2013). Personally tax aggressive executives and corporate tax sheltering. Journal of Accounting and Economics, 56(2-3), 311-328.

doi:http://dx.doi.org/10.1016/j.jacceco.2013.09.003

Coles, J. W., \& Hesterly, W. S. (2000). Independence of the Chairman and Board

Composition: Firm Choices and Shareholder Value. Journal of Management, 26(2), 195214. doi:10.1177/014920630002600202

Collins, J. H., Milliron, V. C., \& Toy, D. R. (1992). Determinants of Tax Compliance: A Contingency Approach. Journal of the American Taxation Association, 14(2), 1-29. Retrieved from http://search.ebscohost.com/login.aspx?direct=true \&db=buh\&AN=6151465\&site=ehost$\underline{\text { live }}$

Cronqvist, H., Makhija, A. K., \& Yonker, S. E. (2012). Behavioral consistency in corporate finance: CEO personal and corporate leverage. Journal of Financial Economics, 103(1), 20-40. doi:http://dx.doi.org/10.1016/j.jfineco.2011.08.005

Davidson, R. H., Dey, A., \& Smith, A. (2015). Executives' “off-the-job” behavior, corporate culture, and financial reporting risk. Journal of Financial Economics, 117(1), 5-28.

Dejong, D., \& Ling, Z. (2013). Managers: Their Effects on Accruals and Firm Policies. Journal of Business Finance \& Accounting, 40(1), 82-114. doi:10.1111/jbfa.12012

Donohoe, M. P., \& Knechel, W.R. (2014). Does Corporate Tax Aggressiveness Influence Audit Pricing? Contemporary Accounting Research, 31(1), 284-308. doi:10.1111/19113846.12027

Dyreng, S. D., Hanlon, M., \& Maydew, E. L. (2008). Long-run corporate tax avoidance. The Accounting Review, 83(1), 61-82.

Dyreng, S. D., Hanlon, M., \& Maydew, E. L. (2010). The Effects of Executives on Corporate Tax Avoidance. The Accounting Review, 85(4), 1163-1189.

doi:10.2308/accr.2010.85.4.1163

Fee, C. E., Hadlock, C. J., \& Pierce, J. R. (2013). Managers with and without Style: Evidence Using Exogenous Variation. Review of Financial Studies, 26(3), 567-601. doi:http://rfs.oxfordjournals.org/content/by/year

Fich, E. M., \& Shivdasani, A. (2006). Are Busy Boards Effective Monitors? The Journal of Finance, 61(2), 689-724. Retrieved from http://www.jstor.org/stable/3699355 
Francis, B. B., Hasan, I., Wu, Q., \& Yan, M. (2014). Are Female CFOs Less Tax Aggressive? Evidence from Tax Aggressiveness. The Journal of the American Taxation Association, 36(2), 171-202. doi:10.2308/atax-50819

Funder, D. C., \& Colvin, C. R. (1991). Explorations in behavioral consistency: properties of persons, situations, and behaviors. Journal of Personality and Social Psychology, 60(5), 773-794.

Ge, W., Matsumoto, D., \& Zhang, J. L. (2011). Do CFOs Have Style? An Empirical Investigation of the Effect of Individual CFOs on Accounting Practices. Contemporary Accounting Research, 28(4), 1141-1179.

Ghosh, D., \& Crain, T. L. (1996). Experimental Investigation of Ethical Standards and Perceived Probability of Audit on Intentional Noncompliance. Behavioral Research in Accounting, 8, 219-244. Retrieved from http://search.ebscohost.com/login.aspx?direct=true \&db=buh\&AN=7709773\&site=ehost$\underline{\text { live }}$

Guenther, D. A. (1994). Earnings management in response to corporate tax rate changes: Evidence from the 1986 Tax Reform Act. Accounting Review, 69(1), 230-243.

Gupta, S., \& Newberry, K. (1997). Determinants of the variability in corporate effective tax rates: Evidence from longitudinal data. Journal of Accounting and Public Policy, 16(1), 1-34. doi:http://dx.doi.org/10.1016/S0278-4254(96)00055-5

Habib, A., \& Hossain, M. (2013). CEO/CFO characteristics and financial reporting quality: A review. Research in Accounting Regulation, 25(1), 88-100. doi:https://doi.org/10.1016/j.racreg.2012.11.002

Hambrick, D. C., \& Mason, P. A. (1984). Upper Echelons: The Organization as a Reflection of Its Top Managers. Academy of Management Review, 9(2), 193-206. doi:10.5465/AMR.1984.4277628

Hanno, D. M., \& Violette, G. R. (1996). An Analysis of Moral and Social Influences on Taxpayer Behavior. Behavioral Research in Accounting, 8, 57-75. Retrieved from http://search.ebscohost.com/login.aspx?direct=true \&db=buh\&AN=7709432\&site=ehost$\underline{\text { live }}$

Henderson, B. C., \& Kaplan, S. E. (2005). An Examination of the Role of Ethics in Tax Compliance Decisions. Journal of the American Taxation Association, 27(1), 39-72. Retrieved from http://search.ebscohost.com/login.aspx?direct=true \&db=buh\&AN=17075287\&site=ehost -live

Henry, E., \& Sansing, R. (2018). Corporate tax avoidance: data truncation and loss firms. Review of Accounting Studies, 23(3), 1042-1070.

Hermalin, B. E., \& Weisbach, M. S. (2003). Boards of directors as an endogenously determined institution: A survey of the economic literature. Economic Policy Review, 9(1), 7-26. 
Jensen, M. C. (1993). The modern industrial revolution, exit, and the failure of internal control systems. The Journal of Finance, 48(3), 831-880.

Kallunki, J., \& Pyykkö, E. (2013). Do defaulting CEOs and directors increase the likelihood of financial distress of the firm? Review of Accounting Studies, 18(1), 228-260. doi:http://dx.doi.org/10.1007/s11142-012-9203-x

Kaplan, S. E., Newberry, K. J., \& Reckers, P. M. (1997). The effect of moral reasoning and educational communications on tax evasion intentions. The Journal of the American Taxation Association, 19(2), 38-54.

Kaplan, S. N., Klebanov, M. M., \& Sorensen, M. (2012). Which CEO Characteristics and Abilities Matter? Journal of Finance, 67(3), 973-1007.

Klassen, K. J. (1997). The impact of inside ownership concentration on the trade-off between financial and tax reporting. Accounting Review,72(3), 455-474.

Law, K. K., \& Mills, L. F. (2016). Military experience and corporate tax avoidance. Review of Accounting Studies, 22(1), 141-184.

Malmendier, U., \& Tate, G. (2005). CEO Overconfidence and Corporate Investment. Journal of Finance, 60(6), 2661-2700. doi:10.1111/j.1540-6261.2005.00813.x

Malmendier, U., \& Tate, G. (2008). Who makes acquisitions? CEO overconfidence and the market's reaction. Journal of Financial Economics, 89(1), 20-43.

doi:http://dx.doi.org/10.1016/j.jfineco.2007.07.002

Malmendier, U., Tate, G., \& Yan, J. (2011). Overconfidence and Early-Life Experiences: The Effect of Managerial Traits on Corporate Financial Policies. The Journal of Finance, 66(5), 1687-1733. doi:10.1111/j.1540-6261.2011.01685.x

Mischel, W., \& Shoda, Y. (1995). A cognitive-affective system theory of personality: reconceptualizing situations, dispositions, dynamics, and invariance in personality structure. Psychological Review, 102(2), 246-268.

Murray, C. (1998). Income inequality and IQ. Washington: AEI Press.

Olsen, K. J., \& Stekelberg, J. (2015). CEO narcissism and corporate tax sheltering. The Journal of the American Taxation Association, 38(1), 1-22.

Penno, M., \& Simon, D. T. (1986). Accounting choices: Public versus private firms. Journal of Business Finance \& Accounting, 13(4), 561-569.

Platt, H., \& Platt, M. (2012). Corporate board attributes and bankruptcy. Journal of Business Research, 65(8), 1139-1143. doi:http://dx.doi.org/10.1016/j.jbusres.2011.08.003

Reckers, P. M., Sanders, D. L., \& Roark, S. J. (1994). The influence of ethical attitudes on taxpayer compliance. National Tax Journal, 47(4), 825-836. 
Schooley, D., Renner, C., \& Allen, M. (2010). Shareholder Proposals, Board Composition, and Leadership Structure. Journal of Managerial Issues, 22(2), 152-165. Retrieved from http://www.jstor.org/stable/20798902

Schrand, C. M., \& Zechman, S. L. C. (2012). Executive overconfidence and the slippery slope to financial misreporting. Journal of Accounting and Economics, 53(1-2), 311-329. doi:http://dx.doi.org/10.1016/j.jacceco.2011.09.001

Schwab, K., \& Porter, M. E. (2006). The Global Competitiveness Report: World Economic Forum.

Sheffrin, S., \& Triest, R. (1992). Can brute deterrence backfire? Perceptions and attitudes in taxpayer compliance. In J. Slemrod (Ed.), Why People Pay Taxes: Tax Compliance and Enforcement (pp. 193-218) University of Michigan Press.

Sundvik, D. (2017). Book-tax conformity and earnings management in response to tax rate cuts. Journal of International Accounting, Auditing and Taxation, 28, 31-42.

Tangney, J. P., Stuewig, J., \& Mashek, D. J. (2007). Moral emotions and moral behavior. Annual Review of Psychology, 58, 345-372.

doi:10.1146/annurev.psych.56.091103.070145 [doi]

The Swedish Tax Agency. (2011). Taxes in Sweden 2010: An English Summary of Tax Statistical Yearbook of Sweden. Retrieved from http://www.skatteverket.se/download/18.616b78ca12d1247a4b2800025728/10411.pdf.

Uzun, H., Szewczyk, S. H., \& Varma, R. (2004). Board Composition and Corporate Fraud. Financial Analysts Journal, 60(3), 33-43. Retrieved from http://www.jstor.org/stable/4480570

World Bank. (2019). Worldwide Governance Indicators. Retrieved from www.govindicators.org

Zajac, E. J., \& Westphal, J. D. (1996). Who shall succeed? How CEO/board preferences and power affect the choice of new CEOs. Academy of Management Journal, 39(1), 64-90. 


\section{Appendix: Variable Descriptions}

\begin{tabular}{|c|c|}
\hline Variable & Description \\
\hline \multicolumn{2}{|c|}{ Measures of corporate tax avoidance } \\
\hline$B T D_{f t}$ & $\begin{array}{l}\text { Difference between expected total tax and reported total tax, scaled } \\
\text { by lagged total assets. Winsorized at } 1 \% \text { and } 99 \% \text {. }\end{array}$ \\
\hline$C T D_{f t}$ & $\begin{array}{l}\text { Difference between expected total tax and reported cash tax, scaled } \\
\text { by lagged total assets. Winsorized at } 1 \% \text { and } 99 \% \text {. }\end{array}$ \\
\hline$C R T D_{f t}$ & $\begin{array}{l}\text { Difference between expected total tax and reported current portion } \\
\text { of total tax, scaled by lagged total assets. Winsorized at } 1 \% \text { and } \\
99 \% \text {. }\end{array}$ \\
\hline GAAPETR $_{f t}$ & $\begin{array}{l}\text { Ratio of total tax to pretax income, adjusted for special items. } \\
\text { Winsorized at } 0 \text { and } 1 \text {. }\end{array}$ \\
\hline CURRETR $R_{f t}$ & $\begin{array}{l}\text { Ratio of current portion of total tax to pretax income, adjusted for } \\
\text { special items. Winsorized at } 0 \text { and } 1 .\end{array}$ \\
\hline CASHETR $_{f t}$ & $\begin{array}{l}\text { Ratio of cash taxes paid to pretax income, adjusted for special items. } \\
\text { Winsorized at } 0 \text { and } 1 .\end{array}$ \\
\hline CONFTAX $X_{f t}$ & $\begin{array}{l}\text { Measure of conforming tax avoidance following Badertscher, Katz, } \\
\text { Rego, and Wilson (2019). Estimated for industry-year combinations } \\
\text { with at least six observations. Winsorized at } 1 \% \text { and } 99 \% \text {. }\end{array}$ \\
\hline \multicolumn{2}{|c|}{ Measures of personal tax behavior } \\
\hline $\mathrm{MATCH}_{i}$ & $\begin{array}{l}\text { Indicator variable equal to } 1 \text { if an executive has matched capital } \\
\text { gains (including deposit income) and losses (including management } \\
\text { costs) during at least } 70 \% \text { of the years in which the executive has } \\
\text { appeared in the sample. }\end{array}$ \\
\hline RECLASS & $\begin{array}{l}\text { Indicator variable equal to } 1 \text { if an executive has received more than } \\
500,000 \text { SEK in dividend income from a closely held company (a } \\
\text { company that pays dividends to no more than five individuals) in at } \\
\text { least one year in the sample. }\end{array}$ \\
\hline LATETAX & $\begin{array}{l}\text { Indicator variable equal to } 1 \text { if an executive has filed late personal } \\
\text { tax returns for at least one year in the sample. }\end{array}$ \\
\hline$T_{A X E R R O R}$ & $\begin{array}{l}\text { Indicator variable equal to } 1 \text { if an executive has filed incorrect } \\
\text { personal tax returns for at least one year in the sample. }\end{array}$ \\
\hline TAXEXTREME & $\begin{array}{l}\text { Indicator variable equal to } 1 \text { if an executive has been suspected of } \\
\text { tax-related criminal activity at least once since } 1991 \text { or convicted of } \\
\text { such activity at least once since } 1974 \text {. }\end{array}$ \\
\hline TAXTOTAL ${ }_{i}$ & $\begin{array}{l}\text { Personal tax behavior measure, calculated as the sum of the } \\
M A T C H_{i}, \quad R E C L A S S_{i}, \quad L A T E T A X_{i}, \quad T A X E R R O R_{i}, \\
\text { TAXEXTREME and } \\
\text { indicator variables. }\end{array}$ \\
\hline \multicolumn{2}{|c|}{ Measures considered as determinants of personal tax behavior } \\
\hline$A G E_{i}$ & $\begin{array}{l}\text { Executive age at the beginning of the sample period, i.e., in } 1999 . \\
\text { Calculated as difference between } 1999 \text { and birth year. }\end{array}$ \\
\hline TOTALCRIME & $\begin{array}{l}\text { Number of crimes of which an executive has been suspected (since } \\
\text { 1991) or convicted (since 1974). }\end{array}$ \\
\hline NBANKRUPTCY $Y_{i}$ & $\begin{array}{l}\text { The number of bankruptcies of listed or private companies in which } \\
\text { the executive has been involved as either a CEO or a board member } \\
\text { during the sample period. Winsorized at } 99 \% \text {. }\end{array}$ \\
\hline$W E A L T H_{i}$ & $\begin{array}{l}\text { Natural logarithm of the average net wealth during the tenure period } \\
\text { in thousands of SEK. Winsorized at } 1 \% \text { and } 99 \% \text {. }\end{array}$ \\
\hline
\end{tabular}


$S A L A R Y_{i}$

SSEDEGREE
Natural logarithm of the average salary during the tenure period in thousands of SEK. Winsorized at $1 \%$ and $99 \%$.

Indicator variable equal to 1 if an executive has a degree from the Stockholm School of Economics and 0 otherwise.

Control variables for corporate tax avoidance

PROF_BOARD $D_{f t}$

FEMALE_BOARD $D_{f t}$ $B O A R D S I Z E_{f t}$

$O P T_{-} I N C_{f t}$

CEO_INS $S_{f t}$

CFO_INS $S_{f t}$

CHAIR_INS $S_{f t}$

$I N S T \_B L O C K_{f t}$

CEO_OWNERSHIP ${ }_{f t}$ $S I Z E_{f t}$

$E_{B I T D A_{f t}}$

$R \& D_{f t}$

$S G \& A_{f t}$

CAPEX $X_{f t}$

$C h S A L E_{f t}$

LEVERAGE $E_{f t}$

$\mathrm{CASH}_{f t}$

INTANGRATIO $O_{f t}$

PPERATIO ${ }_{f t}$

$P T_{-} R O A_{f t}$

$N O L_{f t}$

$F S_{f t}$

INDUSTRY

$Y E A R$
Proportion of board members who have three or more board assignments at the end of the year.

Proportion of female board members at the end of the year.

Board size at the end of the year.

Indicator variable set to 1 if the firm reports having option incentive structures in a given year, and 0 otherwise.

Proportion of insider holdings in total CEO wealth in a given year, in percent.

Proportion of insider holdings in total CFO wealth in a given year, in percent.

Proportion of insider holdings in total CEO wealth in a given year, in percent.

Number of institutional blockholders that hold more than $5 \%$ of the shares.

Proportion of the shares held by the CEO and her family, in percent.

Natural logarithm of total assets in thousands of SEK. Winsorized at $1 \%$ and $99 \%$.

Operating income before depreciation over lagged total assets. Winsorized at $1 \%$ and $99 \%$.

Research and development expenses over total sales. Winsorized at $1 \%$ and $99 \%$.

Selling, general and administrative expenses over total sales. Winsorized at $1 \%$ and $99 \%$.

Capital expenditures over gross PP\&E. Winsorized at $1 \%$ and $99 \%$. Yearly percentage change in sales. Winsorized at $1 \%$ and $99 \%$.

Total debt over total assets. When debt is unavailable, calculated as (total assets - owners' equity)/(total assets). Winsorized at $1 \%$ and 99\%.

Cash and equivalents over total assets. Winsorized at $1 \%$ and $99 \%$. Intangible assets over total assets. Winsorized at $1 \%$ and $99 \%$.

Gross PP\&E over total assets. Winsorized at $1 \%$ and $99 \%$.

Pretax income over lagged total assets. Winsorized at $1 \%$ and $99 \%$. Indicator variable equal to 1 if a firm had at least one loss year over the last 3 years.

Indicator variable equal to 1 if a firm reported positive foreign sales in a given year.

Indicator variables for industries, based on the Fama-French 12industry classification.

Indicator variable for the financial year. 
TABLE 1

Sample construction

\begin{tabular}{lcc}
\hline & $\begin{array}{c}\text { Lost } \\
\text { observations }\end{array}$ & $\begin{array}{c}\text { Firm-year } \\
\text { observations }\end{array}$ \\
\hline Total number of firm-years & -137 & 2,862 \\
Cases with executive tax behavior data not available & -683 & 2,725 \\
Cases with company tax behavior data not available & -12 & 2,042 \\
$\begin{array}{l}\text { Cases with industry codes not available } \\
\text { Cases with data on financial leverage and firm size not }\end{array}$ & -5 & 2,030 \\
$\begin{array}{l}\text { available } \\
\text { Firm years with executives likely suspected or convicted of }\end{array}$ & -15 & 2,010 \\
corporate tax evasion & & $\mathbf{2 , 0 1 0}$ \\
Final sample & & \\
& & 627 \\
Number of individual CEOs in the sample & & 508 \\
Number of individual CFOs in the sample & & 446 \\
\hline
\end{tabular}

Notes:

1. This table reports our sample construction. The sample covers firms listed on the OMX Stockholm Stock Exchange with available CEO, CFO, and Board Chairperson tax behavior data. The sample period is from 1999 to 2007.

2. Personal data are from the Swedish Tax Agency (Skatteverket), the Swedish National Council for Crime Prevention $(B r a ̊)$, the Swedish National Service Administration, the credit bureau UC, and Statistics Sweden.

3. Accounting data are from Compustat Global Vantage. In the few cases of missing data in Compustat Global Vantage, we retrieved the missing data from Datastream and from the financial reports of the sample firms. All tax items that were equal to zero in the databases have been manually checked in the financial reports. 


\section{TABLE 2}

Frequency distributions of executives' personal tax behavior measures

\begin{tabular}{|c|c|c|c|c|}
\hline \multicolumn{5}{|c|}{ Panel A: Different measures of executives' personal tax behavior } \\
\hline & $\begin{array}{c}\text { Full sample } \\
(\mathrm{N}=1,446)\end{array}$ & $\begin{array}{c}\text { CEOs } \\
(\mathrm{N}=627)\end{array}$ & $\begin{array}{c}\text { CFOs } \\
(\mathrm{N}=508)\end{array}$ & $\begin{array}{l}\text { Chairs } \\
(\mathrm{N}=446)\end{array}$ \\
\hline MATCH $_{i}$ & $188(13.00 \%)$ & $69(11.00 \%)$ & $38(7.48 \%)$ & $99(22.20 \%)$ \\
\hline RECLASS & $44(3.04 \%)$ & $18(2.87 \%)$ & $2(0.39 \%)$ & $32(7.17 \%)$ \\
\hline LATETAX & $97(6.71 \%)$ & $56(8.93 \%)$ & $10(1.97 \%)$ & $42(9.42 \%)$ \\
\hline TAXERROR $_{i}$ & $59(4.08 \%)$ & $30(4.78 \%)$ & $12(2.36 \%)$ & $25(5.61 \%)$ \\
\hline TAXEXTREME & $30(3.09 \%)$ & $17(2.71 \%)$ & $0(0.00 \%)$ & $15(3.36 \%)$ \\
\hline \multicolumn{5}{|c|}{ Panel B: Composite measure of executives' personal tax behavior } \\
\hline TAXTOTAL $L_{i}=$ & $\begin{array}{c}\text { Full sample } \\
(\mathrm{N}=1,446)\end{array}$ & $\begin{array}{c}\text { CEOs } \\
(\mathrm{N}=627)\end{array}$ & $\begin{array}{c}\text { CFOs } \\
(\mathrm{N}=508)\end{array}$ & $\begin{array}{l}\text { Chairs } \\
(\mathrm{N}=446)\end{array}$ \\
\hline 0 & $1091(75.45 \%)$ & $465(74.16 \%)$ & $450(88.58 \%)$ & $273(61.21 \%)$ \\
\hline 1 & $293(20.26 \%)$ & $135(21.53 \%)$ & $54(10.63 \%)$ & $135(30.27 \%)$ \\
\hline 2 & $58(4.01 \%)$ & $24(3.83 \%)$ & $4(0.79 \%)$ & $36(8.07 \%)$ \\
\hline 3 & $4(0.28 \%)$ & $3(0.48 \%)$ & $0(0.00 \%)$ & $2(0.45 \%)$ \\
\hline
\end{tabular}

Notes:

1. This table reports frequency distributions of the individual personal tax behavior measures (Panel A) and composite personal tax behavior measure (Panel B). The sample covers CEOs, CFOs, and Chairpersons of all firms listed on the OMX Stockholm Stock Exchange. The sample period is from 1999 to 2007.

2. All variables are as defined in Section 'Variable Measurement' and in the Appendix. 
TABLE 3

Summary statistics on executives' personal characteristics $(N=1,391)$

\begin{tabular}{lrrrrrrr}
\hline & Mean & Std. dev. & Min & P25 & Median & P75 & Max \\
\hline AGE $_{i}$ & 45.46 & 9.50 & 20 & 38 & 45 & 53 & 75 \\
TOTALCRIME $_{i}$ & 0.39 & 0.80 & 0 & 0 & 0 & 1 & 8 \\
NBANKRUPTCY $_{i}$ & 1.31 & 2.92 & 0 & 0 & 0 & 1 & 35 \\
$\begin{array}{l}\text { WEALTH } \\
\text { (in millions of SEK) }\end{array}$ & 53.70 & $1,251.87$ & -23.63 & 1.28 & 3.48 & 10.800 & $46,473.40$ \\
SALARY $_{i}$ & & & & & & & \\
(in millions of SEK) & 2.01 & 2.18 & 0 & 0.76 & 1.25 & 2.42 & 17.84 \\
SSEDEGREE $_{i}$ & 0.16 & 0.37 & 0 & 0 & 0 & 0 & 1 \\
TAXTOTAL $_{i}$ & 0.30 & 0.57 & 0 & 0 & 0 & 0 & 3 \\
\hline
\end{tabular}

Notes:

1. This table reports summary statistics for the CEO, CFO, and Board Chairperson characteristics. The sample covers executives in firms listed on the OMX Stockholm Stock Exchange with all required personal data available. The sample period is from 1999 to 2007.

2. The data are from the Swedish Tax Agency (Skatteverket), the Swedish National Council for Crime Prevention (Brå), the Swedish National Service Administration, UC, and Statistics Sweden.

3. All variables are as defined in Section "Variable Measurement" and in the Appendix. 


\section{TABLE 4}

\section{Descriptive statistics and tests for means and medians}

Panel A: Sample divided into two subsamples based on $C E O \_T A X T O T A L_{f t}$

\begin{tabular}{lcccccc}
\hline & \multicolumn{3}{c}{ CEO_TAXTOTAL } & \multicolumn{2}{c}{ Tests for differences } \\
\hline & \multicolumn{3}{c}{$>1$} & \multicolumn{7}{c}{$=0$} \\
& Mean & Median & Mean & Median & $\Delta$ Mean & $\Delta$ Median \\
\hline BTD $_{f t}$ & -0.008 & -0.001 & -0.015 & -0.002 & $0.007 * * *$ & $0.001^{* * *}$ \\
CRTD $_{f t}$ & -0.009 & 0.001 & -0.014 & -0.001 & $0.005^{*}$ & $0.002^{* * *}$ \\
CTD $_{f t}$ & -0.009 & 0.002 & -0.014 & -0.001 & $0.005^{*}$ & $0.003^{* * *}$ \\
GAAPETR $_{f t}$ & 0.233 & 0.268 & 0.269 & 0.280 & $-0.036^{* * *}$ & $-0.012^{* * *}$ \\
CURRETR $_{f t}$ & 0.193 & 0.176 & 0.233 & 0.226 & $-0.040^{* * *}$ & $-0.050^{* * *}$ \\
CASHETR $_{f t}$ & 0.174 & 0.121 & 0.234 & 0.196 & $-0.060^{* * *}$ & $-0.075^{* * *}$ \\
\hline
\end{tabular}

Panel B: Sample divided into two subsamples based on CFO_TAXTOTAL $L_{f t}$

\begin{tabular}{lcccccc}
\hline & \multicolumn{3}{c}{ CFO_TAXTOTAL $f t$} & \multicolumn{2}{c}{ Tests for differences } \\
\hline & \multicolumn{3}{c}{$>$ 1 } & \multicolumn{3}{c}{$=0$} \\
& Mean & Median & Mean & Median & $\Delta$ Mean & $\Delta$ Median \\
\hline BTD $_{f t}$ & -0.002 & -0.001 & -0.014 & -0.002 & $0.012^{* * *}$ & $0.001^{* *}$ \\
CRTD $_{f t}$ & -0.003 & 0.001 & -0.014 & -0.001 & $0.011^{* * *}$ & 0.002 \\
CTD $_{f t}$ & -0.004 & 0.000 & -0.013 & 0.000 & $0.009 * * *$ & 0.000 \\
GAAPETR $_{f t}$ & 0.271 & 0.285 & 0.256 & 0.277 & -0.015 & 0.007 \\
CURRETR $_{f t}$ & 0.231 & 0.207 & 0.219 & 0.217 & 0.012 & -0.010 \\
CASHETR $_{f t}$ & 0.244 & 0.178 & 0.212 & 0.178 & $0.032^{*}$ & 0.000 \\
\hline
\end{tabular}

Panel C: Sample divided into two subsamples based on CHAIR_TAXTOTAL $L_{f t}$

\begin{tabular}{lcccccc}
\hline & \multicolumn{3}{c}{ CHAIR_TAXTOTAL $f t$} & \multicolumn{2}{c}{ Tests for differences } \\
\hline & \multicolumn{7}{c}{$>$ 1 } & \multicolumn{7}{c}{$=0$} \\
& Mean & Median & Mean & Median & D Mean & $\Delta$ Median \\
\hline BTD $_{f t}$ & -0.012 & -0.002 & -0.014 & -0.002 & 0.002 & 0.000 \\
CRTD $_{f t}$ & -0.011 & 0.000 & -0.014 & -0.001 & 0.003 & 0.001 \\
CTD $_{f t}$ & -0.011 & 0.000 & -0.014 & 0.000 & 0.003 & 0.000 \\
GAAPETR $_{f t}$ & 0.257 & 0.279 & 0.258 & 0.278 & -0.001 & 0.001 \\
CURRETR $_{f t}$ & 0.224 & 0.211 & 0.218 & 0.216 & 0.006 & -0.005 \\
CASHETR $_{f t}$ & 0.219 & 0.184 & 0.213 & 0.172 & 0.006 & 0.012 \\
\hline
\end{tabular}


Notes:

1. This table reports tests for mean and median equality. The sample is partitioned based on CEOs', CFOs', and Board Chairperson's personal tax behavior.

2. Panel A reports partitioning results based on the CEO_TAXTOTAL $L_{f t}$ measure; the number of observations with personally tax-aggressive CEOs is 651 (450 for ETRs). Panel B reports partitioning results based on the CFO_TAXTOTA $L_{f t}$ measure; the number of observations with personally tax-aggressive CFOs is 216 (159 for ETRs). Panel $\mathrm{C}$ reports partitioning results based on the CHAIR_TAXTOTAL $L_{f t}$ measure; the number of observations with personally tax-aggressive Board Chairpersons is 802 (572 for ETRs).

3. All variables are as defined in Section "Variable Measurement" and in the Appendix.

4. $* p<.1 ; * * p<.05 ; * * * p<.01$. 
TABLE 5

Determinants of executives' personal tax behavior measures

\begin{tabular}{|c|c|c|c|c|c|c|c|}
\hline & & $\mathrm{MATCH}_{i}$ & $R E C L A S S_{i}$ & LATETAX $_{i}$ & $T_{A X E R R O R_{i}}$ & $T A X E X T R E M E_{i}$ & TAXTOTAL $_{i}$ \\
\hline & Exp. & $(1)$ & $(2)$ & (3) & (4) & $(5)$ & $(6)$ \\
\hline \multirow[t]{2}{*}{$A G E_{i}$} & $(-)$ & $0.037 * * *$ & -0.013 & -0.017 & 0.021 & 0.023 & 0.0019 \\
\hline & & $(0.01)$ & $(0.02)$ & $(0.013)$ & $(0.015)$ & $(0.022)$ & $(0.008)$ \\
\hline \multirow[t]{2}{*}{ TOTALCRIME $E_{i}$} & $(+)$ & -0.111 & 0.054 & $0.372 * * *$ & $0.293 * *$ & $0.33 * *$ & $0.174 * *$ \\
\hline & & $(0.113)$ & $(0.163)$ & $(0.096)$ & $(0.118)$ & $(0.149)$ & $(0.073)$ \\
\hline \multirow[t]{2}{*}{$N B A N K R U P T C Y_{i}$} & $(+)$ & 0.015 & $0.115^{* * *}$ & $0.06 * *$ & 0.013 & 0.033 & $0.056 * * *$ \\
\hline & & $(0.028)$ & $(0.032)$ & $(0.027)$ & $(0.044)$ & $(0.056)$ & $(0.020)$ \\
\hline \multirow[t]{2}{*}{$W_{E A L T H}$} & $(+)$ & $0.387 * * *$ & $0.657 * * *$ & $0.273 * * *$ & 0.141 & $0.321 * * *$ & $0.455^{* * *}$ \\
\hline & & $(0.06)$ & $(0.102)$ & $(0.072)$ & $(0.09)$ & $(0.115)$ & $(0.048)$ \\
\hline \multirow[t]{2}{*}{$S A L A R Y_{i}$} & $(+)$ & $0.445 * * *$ & 0.053 & $-0.282 * *$ & -0.071 & 0.116 & 0.110 \\
\hline & & $(0.1)$ & $(0.175)$ & $(0.116)$ & $(0.151)$ & $(0.214)$ & $(0.076)$ \\
\hline \multirow[t]{2}{*}{$S S E D E G R E E_{i}$} & $(+/-)$ & 0.03 & 0.337 & -0.373 & $-0.697 *$ & -0.813 & -0.178 \\
\hline & & $(0.209)$ & $(0.377)$ & $(0.331)$ & $(0.403)$ & $(0.623)$ & $(0.076)$ \\
\hline $\mathrm{N}$ & & 1,391 & 1,391 & 1,391 & 1,391 & 1,391 & 1,391 \\
\hline Chi-squared & & 152.06 & 62.44 & 43.35 & 15.62 & 19.99 & 182.54 \\
\hline Pseudo R-squared & & 0.1058 & 0.044 & 0.0314 & 0.011 & 0.014 & 0.126 \\
\hline
\end{tabular}

Notes:

1. This table reports maximum likelihood coefficients from estimating the following ordered logistic regression model:

$$
\begin{aligned}
& \operatorname{Prob}\left(\text { TAXBEH }_{i}\right)=\frac{1}{1+e^{-Z}} \\
& \text { where } Z=\beta_{0}+\beta_{1} A G E_{i}+\beta_{2} \text { TOTALCRIME }_{i}+\beta_{3} N B A N K R U P T C Y_{i}+ \\
& \beta_{4} \text { WEALTH }_{i}+\beta_{5} \text { SALARY }_{i}+\beta_{6} \text { SSEDEGREE }_{i}+\varepsilon
\end{aligned}
$$


2. The sample contains all individuals who have served as CEOs, CFOs, or Board Chairpersons in Swedish listed companies during the period from 1999 to 2007 and have all required personal information available.

3. All variables are as defined in Section "Variable Measurement" and in the Appendix.

4. $* \mathrm{p}<.1 ; * * \mathrm{p}<.05 ; * * * \mathrm{p}<.01$. Standard errors of the estimated parameters are reported in parentheses. 
TABLE 6

Executives' personal tax behavior and corporate tax avoidance

\begin{tabular}{|c|c|c|c|c|c|c|}
\hline \multicolumn{7}{|c|}{ Panel A: Book-tax differences as dependent variables } \\
\hline \multirow[t]{2}{*}{ Dependent: } & $B T D_{f t}$ & $B T D_{f t}$ & $C R T D_{f t}$ & $C R T D_{f t}$ & $C T D_{f t}$ & $C T D_{f t}$ \\
\hline & $(1)$ & $(2)$ & (3) & $(4)$ & $(5)$ & $(6)$ \\
\hline \multirow[t]{2}{*}{ CEO_TAXTOTAL $L_{f t}$} & $0.003 * *$ & & $0.003^{*}$ & & $0.003 * *$ & \\
\hline & $(0.002)$ & & $(0.001)$ & & $(0.001)$ & \\
\hline \multirow[t]{2}{*}{$C E O \_M A T C H H_{f t}$} & & 0.000 & & 0.000 & & 0.000 \\
\hline & & $(0.003)$ & & $(0.003)$ & & $(0.003)$ \\
\hline \multirow[t]{2}{*}{$C E O \_R E C L A S S_{f t}$} & & 0.001 & & 0.000 & & 0.004 \\
\hline & & $(0.003)$ & & $(0.004)$ & & $(0.004)$ \\
\hline \multirow[t]{2}{*}{ CEO_LATETAX $X_{f t}$} & & 0.006 & & $0.005^{*}$ & & 0.001 \\
\hline & & $(0.004)$ & & $(0.003)$ & & $(0.002)$ \\
\hline \multirow[t]{2}{*}{$C E O \_T A X E R R O R_{f t}$} & & $0.009^{*}$ & & 0.003 & & $0.008^{* * * *}$ \\
\hline & & $(0.005)$ & & $(0.004)$ & & $(0.003)$ \\
\hline \multirow[t]{2}{*}{$C E O \_T A X E X T R E M E_{f t}$} & & $0.011^{*}$ & & 0.003 & & 0.002 \\
\hline & & $(0.006)$ & & $(0.004)$ & & $(0.004)$ \\
\hline \multirow[t]{2}{*}{$C F O \_T A X T O T A L_{f t}$} & $0.006^{* *}$ & & $0.006 * * *$ & & $0.004^{* * *}$ & \\
\hline & $(0.002)$ & & $(0.002)$ & & $(0.002)$ & \\
\hline \multirow[t]{2}{*}{$C F O \_M A T C H_{f t}$} & & 0.004 & & $0.003 *$ & & 0.003 \\
\hline & & $(0.003)$ & & $(0.002)$ & & $(0.002)$ \\
\hline \multirow[t]{2}{*}{$C F O \_R E C L A S S_{f t}$} & & 0.016 & & 0.001 & & $-0.016^{* * *}$ \\
\hline & & $(0.015)$ & & $(0.012)$ & & $(0.005)$ \\
\hline \multirow[t]{2}{*}{$C F O \_L A T E T A X_{f t}$} & & $0.010^{* * *}$ & & $0.012 * * *$ & & $0.008^{* *}$ \\
\hline & & $(0.003)$ & & $(0.004)$ & & $(0.003)$ \\
\hline \multirow[t]{2}{*}{ CFO_TAXERROR $R_{f t}$} & & 0.009 & & $0.012^{*}$ & & $0.009 * *$ \\
\hline & & $(0.008)$ & & $(0.006)$ & & $(0.004)$ \\
\hline \multirow[t]{2}{*}{ CHAIR_TAXTOTAL $L_{f t}$} & 0.000 & & -0.001 & & -0.001 & \\
\hline & $(0.002)$ & & $(0.001)$ & & $(0.001)$ & \\
\hline \multirow[t]{2}{*}{$C H A I R \_M A T C H_{f t}$} & & $-0.004 *$ & & -0.003 & & $-0.004 * *$ \\
\hline & & $(0.002)$ & & $(0.002)$ & & $(0.002)$ \\
\hline \multirow[t]{2}{*}{$C H A I R \_R E C L A S S_{f t}$} & & -0.001 & & -0.002 & & 0.000 \\
\hline & & $(0.005)$ & & $(0.005)$ & & $(0.005)$ \\
\hline \multirow[t]{2}{*}{ CHAIR_LATETAX $X_{f t}$} & & $0.011 * * *$ & & $0.006^{* *}$ & & $0.005^{* *}$ \\
\hline & & $(0.003)$ & & $(0.002)$ & & $(0.002)$ \\
\hline \multirow[t]{2}{*}{$C H A I R \_T A X E R R O R_{f t}$} & & -0.004 & & 0.001 & & 0.004 \\
\hline & & $(0.004)$ & & $(0.003)$ & & $(0.003)$ \\
\hline \multirow[t]{2}{*}{ CHAIR_TAXEXTREME $E_{f t}$} & & 0.002 & & -0.003 & & -0.001 \\
\hline & & $(0.003)$ & & $(0.003)$ & & $(0.003)$ \\
\hline Intercept & Yes & Yes & Yes & Yes & Yes & Yes \\
\hline Controls, year, industry FE & Yes & Yes & Yes & Yes & Yes & Yes \\
\hline $\mathrm{N}$ & 2010 & 2010 & 2010 & 2010 & 2010 & 2010 \\
\hline Adj R-squared & 0.7348 & 0.7369 & 0.8215 & 0.8231 & 0.8342 & 0.8371 \\
\hline
\end{tabular}




\begin{tabular}{|c|c|c|c|c|c|c|}
\hline Dependent: & $\begin{array}{l}G A A P \\
E T R_{f t}\end{array}$ & $\begin{array}{l}\text { GAAP } \\
E_{\text {ETR }}\end{array}$ & $\begin{array}{l}C U R R \\
E_{T T R_{f t}}\end{array}$ & $\begin{array}{l}C U R R \\
E_{T T R_{f t}}\end{array}$ & $\begin{array}{l}\text { CASH } \\
\text { ETR }_{f t}\end{array}$ & $\begin{array}{l}C A S H \\
E^{2} R_{f t}\end{array}$ \\
\hline & $(1)$ & $(2)$ & (3) & $(4)$ & $(5)$ & $(6)$ \\
\hline CEO_TAXTOTAL $L_{f t}$ & $\begin{array}{l}-0.032 * * * \\
(0.009)\end{array}$ & & $\begin{array}{l}-0.035^{* * * *} \\
(0.010)\end{array}$ & & $\begin{array}{l}-0.050^{* * * *} \\
(0.010)\end{array}$ & \\
\hline$C E O \_M A T C H_{f t}$ & & $\begin{array}{l}-0.028^{*} \\
(0.016)\end{array}$ & & $\begin{array}{c}0.003 \\
(0.018)\end{array}$ & & $\begin{array}{l}-0.007 \\
(0.019)\end{array}$ \\
\hline$C E O \_R E C L A S S_{f t}$ & & $\begin{array}{l}-0.044 * \\
(0.025)\end{array}$ & & $\begin{array}{l}-0.043 \\
(0.041)\end{array}$ & & $\begin{array}{l}-0.105^{* * *} \\
(0.034)\end{array}$ \\
\hline$C E O \_L A T E T A X_{f t}$ & & $\begin{array}{l}-0.032 \\
(0.022)\end{array}$ & & $\begin{array}{l}-0.049 * * \\
(0.021)\end{array}$ & & $\begin{array}{l}-0.022 \\
(0.022)\end{array}$ \\
\hline CEO_TAXERROR $R_{f t}$ & & $\begin{array}{l}-0.067 * * * \\
(0.021)\end{array}$ & & $\begin{array}{l}-0.084 * * * \\
(0.023)\end{array}$ & & $\begin{array}{l}-0.104^{* * *} \\
(0.025)\end{array}$ \\
\hline CEO_TAXEXTREME $E_{f t}$ & & $\begin{array}{l}-0.034 \\
(0.026)\end{array}$ & & $\begin{array}{l}-0.013 \\
(0.03)\end{array}$ & & $\begin{array}{l}-0.053 * * \\
(0.023)\end{array}$ \\
\hline CFO_TAXTOTAL $L_{f t}$ & $\begin{array}{l}-0.006 \\
(0.014)\end{array}$ & & $\begin{array}{l}-0.010 \\
(0.018)\end{array}$ & & $\begin{array}{c}0.012 \\
(0.018)\end{array}$ & \\
\hline$C F O \_M A T C H_{f t}$ & & $\begin{array}{c}0.005 \\
(0.018)\end{array}$ & & $\begin{array}{c}0.015 \\
(0.021)\end{array}$ & & $\begin{array}{c}0.015 \\
(0.022)\end{array}$ \\
\hline CFO_RECLASS $S_{f t}$ & & $\begin{array}{l}-0.097 \\
(0.143)\end{array}$ & & $\begin{array}{l}-0.088 \\
(0.094)\end{array}$ & & $\begin{array}{l}0.282^{* *} \\
(0.123)\end{array}$ \\
\hline CFO_LATETAX $X_{f t}$ & & $\begin{array}{l}-0.037^{*} \\
(0.020)\end{array}$ & & $\begin{array}{l}-0.066^{* * *} \\
(0.025)\end{array}$ & & $\begin{array}{l}-0.026 \\
(0.028)\end{array}$ \\
\hline CFO_TAXERROR $R_{f t}$ & & $\begin{array}{l}-0.003 \\
(0.026)\end{array}$ & & $\begin{array}{l}-0.059 \\
(0.04)\end{array}$ & & $\begin{array}{l}-0.027 \\
(0.037)\end{array}$ \\
\hline CHAIR_TAXTOTAL $L_{f t}$ & $\begin{array}{l}-0.009 \\
(0.008)\end{array}$ & & $\begin{array}{l}-0.003 \\
(0.009)\end{array}$ & & $\begin{array}{l}-0.004 \\
(0.009)\end{array}$ & \\
\hline CHAIR_MATCH $H_{f t}$ & & $\begin{array}{l}-0.008 \\
(0.012)\end{array}$ & & $\begin{array}{l}-0.001 \\
(0.014)\end{array}$ & & $\begin{array}{c}0.011 \\
(0.014)\end{array}$ \\
\hline CHAIR_RECLASS $S_{f t}$ & & $\begin{array}{l}-0.007 \\
(0.02)\end{array}$ & & $\begin{array}{l}-0.008 \\
(0.021)\end{array}$ & & $\begin{array}{l}-0.003 \\
(0.023)\end{array}$ \\
\hline$C H A I R \_L A T E T A X_{f t}$ & & $\begin{array}{l}-0.034 \\
(0.023)\end{array}$ & & $\begin{array}{l}-0.008 \\
(0.022)\end{array}$ & & $\begin{array}{l}-0.014 \\
(0.024)\end{array}$ \\
\hline CHAIR_TAXERROR $R_{f t}$ & & $\begin{array}{l}-0.005 \\
(0.017)\end{array}$ & & $\begin{array}{l}-0.04 * \\
(0.023)\end{array}$ & & $\begin{array}{l}-0.067 * * * \\
(0.023)\end{array}$ \\
\hline CHAIR_TAXEXTREME $E_{f t}$ & & $\begin{array}{c}0.015 \\
(0.028)\end{array}$ & & $\begin{array}{c}0.042 * \\
(0.022)\end{array}$ & & $\begin{array}{c}0.028 \\
(0.026)\end{array}$ \\
\hline Intercept & Yes & Yes & Yes & Yes & Yes & Yes \\
\hline Controls, year \& industry FE & Yes & Yes & Yes & Yes & Yes & Yes \\
\hline $\mathrm{N}$ & 1403 & 1403 & 1403 & 1403 & 1403 & 1403 \\
\hline Adj R-squared & 0.1549 & 0.1571 & 0.1679 & 0.1772 & 0.2067 & 0.2201 \\
\hline
\end{tabular}


Notes:

1. These tables report the coefficient results of estimating the following model:

$$
\begin{aligned}
& \operatorname{CORPTAX}_{f t}=\beta_{0}+\beta_{1 a} T A X B E H_{-} C E O_{f t}+\beta_{1 b} T A X B E H_{-} C H A I R_{f t} \\
& +\beta_{1 c} \text { TAXBEH_CFO } f t+\beta_{1 d} L O S S_{f t}+\beta_{1 e} T A X B E H_{-} C E O_{f t} \times L O S S_{f t} \\
& +\beta_{1 f} \text { TAXBEH_CHAIR } f t \times \text { LOSS }_{f t}+\beta_{1 g} T A X B E H_{-} C F O_{f t} \times L_{O S S} \\
& +\sum \text { Controls }+\sum \text { Industry FE }+\sum \text { Year FE }+\varepsilon
\end{aligned}
$$

2. CORPTAX $X_{f t}$ is either BTD $f t$, CTD $_{f t}$, CRTD $_{f t}$, or GAAPETR $f t, \quad$ CURRETR $_{f t}$, CASHETR $_{f t}$. $T A X B E H_{-} C E O_{f t}, T A X B E H_{-} C H A I R_{f t}$, and TAXBEH_CFO $O_{f t}$ are vectors of executive personal tax behavior measures, ranging from the full composite measure $T A X T O T A L_{f t}$ to individual personal tax behavior components.

3. All variables are as defined in Section "Variable Measurement" and in the Appendix.

4. $* p<.1 ; * * p<.05 ; * * * p<.01$. Standard errors of the estimated parameters are reported in parentheses. Standard errors are clustered by firm. 
TABLE 7

Executive turnovers and corporate tax avoidance change

\begin{tabular}{lcccccccc}
\hline \multicolumn{1}{l}{ Panel A: Descriptive statistics } & \multicolumn{1}{c}{ Long-term effects $(\mathrm{N}=516)$} & \multicolumn{3}{c}{ Short-term effects (N = 522) } \\
\hline Variable & $\mathrm{N}$ & Mean & Std Dev & Median & $\mathrm{N}$ & Mean & Std Dev & Median \\
\hline$\Delta B T D_{f t}$ & 313 & 0.007 & 0.057 & 0.001 & 522 & 0.003 & 0.060 & 0.001 \\
$\Delta C R T D_{f t}$ & 313 & 0.006 & 0.050 & 0.001 & 522 & 0.001 & 0.052 & 0.000 \\
$\Delta C T D_{f t}$ & 313 & 0.006 & 0.053 & 0.002 & 522 & 0.002 & 0.055 & 0.000 \\
$\triangle T A X T O T A L_{f t}$ & 313 & -0.048 & 0.638 & 0.000 & 522 & -0.052 & 0.637 & 0.000 \\
\hline
\end{tabular}

\begin{tabular}{lcccc}
\hline \multicolumn{5}{l}{ Panel B: Frequency distribution of TAXTOTAL changes } \\
\hline \multicolumn{7}{c}{ Long-term effects $(\mathrm{N}=516)$} & Short-term effects $(\mathrm{N}=522)$ \\
\hline STAXTOTAL & Frequency & Percent & Frequency & Percent \\
\hline-3 & 1 & 0.19 & 1 & 0.19 \\
-2 & 11 & 2.13 & 11 & 2.11 \\
-1 & 67 & 12.98 & 59 & 13.22 \\
0 & 380 & 73.64 & 384 & 73.56 \\
1 & 47 & 9.50 & 49 & 9.39 \\
2 & 6 & 1.16 & 6 & 1.15 \\
3 & 2 & 0.39 & 2 & 0.38 \\
\hline
\end{tabular}

Panel C: Pearson correlation coefficients

\begin{tabular}{lllllll}
\hline & \multicolumn{2}{c}{ Long-term effects $(\mathrm{N}=516)$} & \multicolumn{3}{c}{ Short-term effects $(\mathrm{N}=522)$} \\
\hline & $\Delta B T D$ & $\Delta C R T D$ & $\Delta C T D$ & $\Delta B T D$ & $\Delta C R T D$ & $\Delta C T D$ \\
\hline & $0.113^{* * *}$ & $0.115^{* * *}$ & $0.131^{* * *}$ & $0.096^{*}$ & $0.087^{* *}$ & $0.088^{* *}$ \\
$\begin{array}{l}\text { ITAXTOTAL } \\
p \text {-value }\end{array}$ & 0.010 & 0.009 & 0.003 & 0.028 & 0.047 & 0.046 \\
\hline
\end{tabular}

Panel D: Multivariate relations

\begin{tabular}{|c|c|c|c|c|c|c|c|}
\hline & & \multicolumn{3}{|c|}{ Long-term effects } & \multicolumn{3}{|c|}{ Short-term effects } \\
\hline & Exp. & $B T D$ & CRTD & $C T D$ & $B T D$ & CRTD & $C T D$ \\
\hline & & $(1)$ & $(2)$ & (3) & $(4)$ & $(5)$ & $(6)$ \\
\hline INTERCEPT & & $\begin{array}{c}0.001 \\
(0.001)\end{array}$ & $\begin{array}{c}0.001 \\
(0.001)\end{array}$ & $\begin{array}{c}0.001 \\
(0.001)\end{array}$ & $\begin{array}{c}0.001 \\
(0.002)\end{array}$ & $\begin{array}{l}0 \\
(0.001)\end{array}$ & $\begin{array}{c}0.001 \\
(0.001)\end{array}$ \\
\hline$\triangle T A X T O T A L$ & + & $\begin{array}{l}0.004 * * \\
(0.002)\end{array}$ & $\begin{array}{l}0.004 * * \\
(0.002)\end{array}$ & $\begin{array}{l}0.005^{* * *} \\
(0.002)\end{array}$ & $\begin{array}{c}0.004 \\
(0.003)\end{array}$ & $\begin{array}{c}0.003 * \\
(0.002)\end{array}$ & $\begin{array}{l}0.003 * * \\
(0.002)\end{array}$ \\
\hline Firm-level controls & & Yes & Yes & Yes & Yes & Yes & Yes \\
\hline $\mathrm{N}$ & & 516 & 516 & 516 & 522 & 522 & 522 \\
\hline Adj R-squared & & 0.693 & 0.771 & 0.787 & 0.609 & 0.704 & 0.770 \\
\hline
\end{tabular}

Notes:

1. These tables report the results from testing the association between executive (CEO and CFO) personal tax behavior change (upon executive change) and changes in corporate tax avoidance. 
2. $\triangle T A X T O T A L$ is the change in in the total of CEO and CFO personal tax behavior. It is calculated as the difference between the total of the previous and current total personal tax behavior of the executive pair $\left(T A X T O T A L_{i}\right) . \triangle B T D, \triangle C T D$, and $\triangle C R T D$ are changes in $B T D_{f t}, C T D_{f t}$, and $C R T D_{f t}$, respectively. The means and medians of the changes reported in Panel A are not statistically different from 0.

3. In the "long-term effects" columns, the changes in the average values of corporate tax avoidance for both former and new executive pair tenures are examined regardless of the tenure duration. In the "short-term effects" columns, only the last year of the former executive pair and the first year of the new executive pair are considered.

4. In Panel D, we control for the changes of the following firm-level variables: SIZE, LEVERAGE, EBITDA, SGA, RD, CAPEX, ChSALE, INTANGRATIO, PPERATIO, and PT_ROA.

5. All variables are as defined in Section "Variable Measurement" and in the Appendix.

6. $* p<.1 ; * * p<.05 ; * * * p<.01$. In Panel D, standard errors of the estimated parameters are reported in parentheses. 


\section{TABLE 8}

\section{Executive characteristics and the hiring decision}

Panel A: Correlations between Board Chairperson and CEO characteristics upon new CEO appointment $(\mathrm{N}=269)$

\begin{tabular}{cclclcc}
\hline & TAX & AGE & SSE & NBANKR.i & TOTAL $_{i}$ & WEALTH $_{i}$ \\
& TOTAL $_{i}$ & & DEGREE $_{i}$ & & CRIME $_{i}$ & \\
\hline Coefficient & -0.012 & $0.170^{* * *}$ & 0.045 & $0.300^{* * * *}$ & 0.007 & 0.093 \\
$p$-value & 0.851 & 0.005 & 0.462 & 0.000 & 0.914 & 0.129 \\
\hline
\end{tabular}

Panel B: Correlations between Board Chairperson and CFO characteristics upon new CFO appointment $(\mathrm{N}=211)$

\begin{tabular}{ccccccc}
\hline & TAX & $A G E_{i}$ & SSE & NBANKR.i $_{\text {. }}$ & TOTAL & WEALTH $_{i}$ \\
& TOTAL $_{i}$ & & DEGREE $_{i}$ & & CRIME $_{i}$ & \\
\hline Coefficient & -0.065 & $0.186^{* * *}$ & 0.327 & $0.151^{* *}$ & -0.049 & $0.142^{* * *}$ \\
$p$-value & 0.344 & 0.001 & 0.637 & 0.035 & 0.487 & 0.061 \\
\hline
\end{tabular}

Panel C: Correlations between CEO and CFO characteristics upon new CFO appointment $(\mathrm{N}=211)$

\begin{tabular}{|c|c|c|c|c|c|c|}
\hline & $\begin{array}{c}\text { TAX } \\
\text { TOTAL }_{i}\end{array}$ & $A G E_{i}$ & $\begin{array}{c}S S E \\
D E G R E E_{i}\end{array}$ & $N_{B A N K R_{. i}}$ & $\begin{array}{l}\text { TOTAL } \\
\text { CRIME }_{i}\end{array}$ & WEALTH $_{i}$ \\
\hline \multirow{2}{*}{$\begin{array}{c}\text { Coefficient } \\
p \text {-value }\end{array}$} & -0.088 & $0.244 * * *$ & 0.061 & $0.386 * * *$ & 0.070 & $0.189 * * *$ \\
\hline & 0.202 & 0.000 & 0.382 & 0.000 & 0.312 & 0.019 \\
\hline \multicolumn{7}{|c|}{ Panel D: Correlations between former and new CEO characteristics $(\mathrm{N}=278)$} \\
\hline & $\begin{array}{c}\text { TAX } \\
\text { TOTAL }_{i}\end{array}$ & $A G E_{i}$ & $\begin{array}{c}S S E \\
D E G R E E_{i}\end{array}$ & $N B A N K R_{. i}$ & $\begin{array}{l}\text { TOTAL } \\
\text { CRIME }_{i}\end{array}$ & WEALTH $_{i}$ \\
\hline \multirow{2}{*}{$\begin{array}{c}\text { Coefficient } \\
p \text {-value }\end{array}$} & 0.021 & $0.240 * * *$ & $0.163 * * *$ & $0.269 * * *$ & -0.060 & $0.189 * * *$ \\
\hline & 0.732 & 0.000 & 0.006 & 0.000 & 0.290 & 0.004 \\
\hline \multicolumn{7}{|c|}{ Panel E: Correlations between former and new CFO characteristics $(\mathrm{N}=221)$} \\
\hline & $\begin{array}{c}\text { TAX } \\
\text { TOTAL } L_{i}\end{array}$ & $A G E_{i}$ & $\begin{array}{c}S S E \\
D E G R E E_{i}\end{array}$ & $N B A N K R_{. i}$ & $\begin{array}{l}\text { TOTAL } \\
\text { CRIME }_{i}\end{array}$ & WEALTH $_{i}$ \\
\hline \multirow{2}{*}{$\begin{array}{c}\text { Coefficient } \\
p \text {-value }\end{array}$} & -0.031 & $0.237 * * *$ & 0.062 & $0.345 * * *$ & 0.110 & 0.081 \\
\hline & 0.644 & 0.001 & 0.412 & 0.000 & 0.143 & 0.306 \\
\hline
\end{tabular}

Notes:

1. This table reports the Pearson correlation coefficients between the characteristics of the CEO and the Board Chairperson upon new CEO appointment (Panel A), between the characteristics of the $\mathrm{CFO}$ and Board Chairperson/CEO upon new CFO appointment (Panels C and D), and between the characteristics of the new and former CEO (Panel B) as well as of the new and former CFO (Panel E).

2. All variables are as defined in Section "Variable Measurement" and in the Appendix.

3. $* p<.1 ; * * p<.05 ; * * * p<.01$. 
TABLE 9

Conforming tax avoidance

\begin{tabular}{lcccccccc}
\hline \multicolumn{2}{l}{ Panel A: Descriptive statistics } \\
\hline \multicolumn{1}{c}{ N } & Mean & St.Dev & Min. & P25 & Median & P75 & Max \\
\hline CONFTAX $X_{f t}$ & 1587 & 0.000 & 0.016 & -0.033 & -0.007 & -0.002 & 0.006 & 0.061 \\
\hline
\end{tabular}

\begin{tabular}{lcc}
\hline \multicolumn{2}{l}{ Panel B: Multivariate associations (dependent: CONFTAX $\left.X_{f t}\right)$} & \\
\hline Intercept & Estimate & St. error \\
CEO_TAXTOTAL $L_{f t}$ & -0.001 & $(0.001)$ \\
CFO_TAXTOTAL $L_{f t}$ & $-0.002^{* * *}$ & $(0.001)$ \\
CHAIR_TAXTOTAL $L_{f t}$ & $-0.003^{* * *}$ & $(0.001)$ \\
SIZE & $0.002^{* *}$ & $(0.001)$ \\
$O P T_{-} I N C_{f t}$ & $0.001^{*}$ & $(0.000)$ \\
CEO_INS & 0.001 & $(0.002)$ \\
CFO_INS & 0.000 & $(0.000)$ \\
CHAIR_INS & $0.002_{f t}^{*}$ & $(0.001)$ \\
INST_BLOCK & 0.000 & $(0.000)$ \\
CEO_OWNERSHIP & 0.000 & $(0.000)$ \\
& 0.000 & \\
N & & \\
Adj.R-squared & 1587 & \\
\hline
\end{tabular}

\begin{tabular}{|c|c|c|c|c|}
\hline Panel C: Pearson corr & seffic & in executive c & cific: & \\
\hline & & erm effects & & erm effects \\
\hline & $\mathrm{N}$ & $\triangle C O N F T A X$ & $\mathrm{~N}$ & $\triangle C O N F T A X$ \\
\hline$\triangle E X E C \_T A X T O T A L$ & 379 & -0.072 & 380 & -0.032 \\
\hline$p$-value & & 0.164 & & 0.544 \\
\hline ACEO_TAXTOTAL & 232 & $-0.156 * *$ & 233 & -0.100 \\
\hline$p$-value & & 0.017 & & 0.127 \\
\hline АCFO_TAXTOTAL & 218 & 0.001 & 219 & 0.001 \\
\hline$p$-value & & 0.900 & & 0.580 \\
\hline
\end{tabular}

Notes:

1. These tables report descriptive statistics and Pearson correlations for $\operatorname{CONFTAX}_{f}$, a conforming tax avoidance behavior measure based on Badertscher, Katz, Rego, and Wilson (2019).

2. CONFTAX $X_{f t}$ is derived using the following regression specification:

$$
\frac{T X P D}{\operatorname{lag}(A T)}_{f t}=\beta_{0}+\beta_{1} B T D_{f t}+\beta_{2} L_{O S S_{f t}}+\beta_{3} B T D_{f t} * L O S S_{f t}+\beta_{4} \frac{S A L E S}{N O A}_{f t}+\beta_{5} N O L_{f t}+\varepsilon_{f t}
$$

3. $\varepsilon_{f t}$ is the residual capturing conforming tax avoidance behavior, denoted CONFTAX $f_{f t}$. The model was run separately for each industry and year combination, with at least six industry-year observations. By design, lower CONFTAX $X_{f t}$ values indicate higher conforming tax avoidance.

4. All variables are as defined in Section "Variable Measurement" and in the Appendix.

5. $* \mathrm{p}<.1 ; * * \mathrm{p}<.05 ; * * * \mathrm{p}<.01$. 


\section{SUPPLEMENTAL DATA AND RESEARCH MATERIALS}

TABLE A1. Summary statistics on executives' personal characteristics by position TABLE A2. Descriptive statistics, tests for means and medians

TABLE A3. Correlations

TABLE A4. Executives' personal tax behavior and corporate tax avoidance

TABLE A5. Executives' personal tax behavior, other characteristics, and corporate tax avoidance

TABLE A6. Alternative specifications for extreme personal tax behavior measures 